Shen Xiaoming (Orcid ID: 0000-0001-9537-3747)

Tian Yuntao (Orcid ID: 0000-0001-5480-9962)

Zhang Shimin (Orcid ID: 0000-0002-2739-1043)

Carter Andrew (Orcid ID: 0000-0002-0090-5868)

Kohn Barry, P. (Orcid ID: 0000-0001-5064-5454)

Liu Rui (Orcid ID: 0000-0002-5292-1456)

\title{
Late Miocene hinterland crustal shortening in the Longmen Shan thrust belt, the eastern margin of the Tibetan Plateau
}

\author{
Xiaoming Shen ${ }^{1}$, Yuntao Tian ${ }^{2,3}$, Guihong Zhang ${ }^{2,3}$, Shimin Zhang ${ }^{1}$, Andrew Carter ${ }^{4}$, \\ Barry Kohn ${ }^{5}$, Pieter Vermeesch ${ }^{6}$, Rui Liu ${ }^{1}$, Wei Li ${ }^{1}$
}

${ }^{1}$ Key Laboratory of Crustal Dynamics, Institute of Crustal Dynamics, China Earthquake Administration, Beijing 100085, China

${ }^{2}$ Guangdong Provincial Key Laboratory of Geodynamics and Geohazards, School of Earth Sciences and Engineering, Sun Yat-sen University, Guangzhou 510275, China

${ }^{3}$ Southern Marine Science and Engineering Guangdong Laboratory, Zhuhai 519082, China

${ }^{4}$ Department of Earth and Planetary Sciences, Birkbeck, University of London, London WC1E 7HX, UK

5 School of Earth Sciences, The University of Melbourne, Melbourne, Victoria 3010, Australia

${ }^{6}$ Department of Earth Sciences, University College London, London WC1E 6BT, UK

This is the author manuscript accepted for publication and has undergone full peer review but has not been through the copyediting, typesetting, pagination and proofreading process, which may lead to differences between this version and the Version of Record. Please cite this article as doi: 10.1029/2019JB018358

This article is protected by copyright. All rights reserved. 


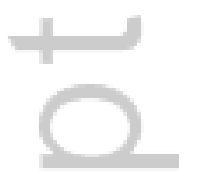

4 


\begin{abstract}
Long-term (million-year time scale) fault-slip history is crucial for understanding the processes and mechanisms of mountain building in active orogens. Such information remains elusive in the Longmen Shan, the eastern Tibetan Plateau margin affected by the devastating 2008 Wenchuan earthquake. Whilst this event drew attention to fault deformation on the foreland side (the Yingxiu-Beichuan fault), little is known about the deformation history of the hinterland Wenchuan-Maoxian fault. To address this gap, thermochronological data were obtained from two vertical transects from the Xuelongbao massif, located in the hanging wall of the Wenchuan-Maoxian fault. The data record late Miocene rapid cooling and rock exhumation at a rate of $0.9-1.2 \mathrm{~km} / \mathrm{m}$.y. from $\sim 13$ Ma to present. The exhumation rate is significantly higher than that in the footwall $(\sim 0.3-0.5 \mathrm{~km} / \mathrm{m} . \mathrm{y}$.$) , indicating a differential$ exhumation of $\sim 0.6 \mathrm{~km} / \mathrm{m}$.y. across the fault. This differential exhumation provides the first and minimum constraint on the long-term throw rate $(\sim 0.6 \mathrm{~km} / \mathrm{m} . \mathrm{y})$ of the Wenchuan-Maoxian fault since the late Miocene. This new result implies continuous crustal shortening along the hinterland fault of Longmen Shan, even though it has not been ruptured by major historic earthquakes. Our study lends support to geodynamic models that highlight crustal shortening as dominating deformation along the eastern Tibetan Plateau.
\end{abstract}

This article is protected by copyright. All rights reserved. 


\section{Introduction}

The Longmen Shan, located at the eastern margin of Tibetan Plateau, forms one of the world's highest continental escarpments (up to $5000 \mathrm{~m}$ relief), and was affected by the devastating $M_{w} 7.9$ Wenchuan earthquake on May 12, 2008 (Fig. 1) [e.g., Liu-Zeng et al., 2009; Xu et al., 2009; Zhang et al., 2010]. The crustal structure of the Longmen Shan is defined by three parallel NW-dipping fault zones, which from foreland to hinterland are the Guanxian-Anxian fault, the Yingxiu-Beichuan fault and the Wenchuan-Maoxian fault. These three faults constitute the Longmen Shan fault zone [Xu et al., 1992; Chen et al., 1995]. The Wenchuan earthquake and aftershocks ruptured the Yingxiu-Beichuan and Guanxian-Anxian faults [e.g., Liu-Zeng et al., 2009; Xu et al., 2009; Ran et al., 2010; Zhang et al., 2010]. However, as the Wenchuan-Maoxian fault on the hinterland side was not activated by the earthquake [e.g., Liu-Zeng et al., 2009; Xu et al., 2009; Ran et al., 2010; Zhang et al., 2010], it has led to a major controversy as to whether the hinterland fault is active or not [Ma et al., 2005; Li et al., 2006; Chen et al., 2007; Zhang et al., 2013; Gao et al., 2016; Wang et al., 2017].

There is also much debate about long-term deformation kinematics of the Longmen Shan fault zone. Whereas previous studies have attained some consensus regarding the Late Cenozoic dextral-thrust and the nature of thrusting of the Yingxiu-Beichuan and Guanxian-Anxian faults [Xu et al., 1992; Burchfiel et al., 1995; Chen et al., 1995; Densmore et al., 2007], discussion continues about the late Cenozoic deformation history of the Wenchuan-Maoxian fault. Using studies on surface deformation and exhumation of the central and southern Longmen Shan, one group of researchers suggested that the fault has accommodated a significant magnitude of east-verging crustal shortening [e.g., Tian et al., 2013; Tan et al., 2017a]. By contrast, another group proposed late Cenozoic normal sense of shearing along the fault [Burchfiel et al., 1995, 2008; Royden et al., 2008]. The structural evidence for normal sense shearing mainly comes from a top-to-the-NW-sense of shear zone preserved in the mylonite belt developed along and west of the Wenchuan-Maoxian fault zone [Burchfiel et al., 1995, 2008; Royden et al., 2008]. However, recent ${ }^{40} \mathrm{Ar} /{ }^{39} \mathrm{Ar}$ dating of recrystallized minerals aligned along the mylonite foliation in the southern Longmen Shan yields ages of 74-58 Ma, indicating that timing of this normal shear deformation is Late 
Cretaceous-earliest Paleogene [Tian et al., 2016]. Based on geomorphic analysis, a third group inferred little or no dip-slip activity [Godard et al., 2009, 2010; Gao et al., 2016].

To gain new insights into the magnitude and timing of relative fault displacement and regional structure, we report new low-temperature thermochronology data using the (U-Th)/He technique on apatite (AHe) and zircon (ZHe), and the fission-track technique on zircon (ZFT) from two vertical profiles across the entire relief of the west side of the Wenchuan-Maoxian fault (Fig.1b and c). These types of data are sensitive to different temperatures ranging from $\sim 70$ to $\sim 250^{\circ} \mathrm{C}$ in the upper crust, thus could provide constraints on different stages of rock cooling and exhumation [e.g., Reiners and Brandon, 2006]. Combined with existing data from the eastern side, our results indicate that long-term differential rock exhumation ( $0.6 \mathrm{~km} / \mathrm{m}$.y.) has occurred along the Wenchuan-Maoxian fault, in response to significant late Miocene east-vergent crustal shortening. Such a differential exhumation magnitude provides a unique constraint on the long-term throw rate along the fault. This long-term slip-rate, which is similar to that along the frontal Yingxiu-Beichuan fault ( $\sim 0.5 \mathrm{~km} / \mathrm{m} . \mathrm{y}$.), suggests that the hinterland fault of the Longmen Shan has also accommodated significant crustal deformation over the long-term, even though it was not ruptured by the 2008 Wenchuan earthquake.

\section{Topographic and geological setting}

The Longmen Shan defines the eastern margin of the highly elevated eastern part of the Tibetan Plateau against the significantly lower foreland, forming the Sichuan Basin, to the east (Figs. 1a and b). Elevations increase abruptly from $\sim 500 \mathrm{~m}$ to peaks exceeding $5000 \mathrm{~m}$ over a distance of $\sim 50 \mathrm{~km}$ from the western Sichuan Basin to the Longmen Shan, making the plateau margin one of the steepest intra-continental escarpments globally.

Structurally, the Longmen Shan is defined by three subparallel faults (Fig. 2) [SBGMR, 1991; Zhao et al., 2012; Li et al., 2013]. The hinterland Wenchuan-Maoxian fault is well documented to be a NW-dipping fault based on NW-dipping foliation in the Paleozoic greenschist [SBGMR, 1991; Burchfiel et al., 1995; Chen et al., 1995; Worley and Wilson, 1996; Yan et al., 2011; Xue et al., 2017] and seismic reflection surfaces [e.g., Hubbard and 
Shaw, 2009; Jin et al., 2010; Robert et al., 2010; Guo et al., 2013; Lu et al., 2014]. Similarly, the geometry of the Yingxiu-Beichuan and Guanxian-Anxian faults are also listric, whose shallow structures are constrained by surface geology and borehole measurements [SBGMR, 1991; Li et al., 2013] and deep structures by seismic reflection profile [Jia et al., 2006; Guo et al., 2013; Feng et al., 2016], thermochronology data [Tian et al., 2013] and coseismic slip of the 2008 Wenchuan earthquake [e.g., Shen et al., 2009; Xu et al., 2009] (Fig. 2c). These three faults merge into a detachment at a depth of 20-30 km [Tian et al., 2013; Feng et al., 2016].

The three faults also control lithology distribution in the Longmen Shan. Between the Wenchuan-Maoxian and Yingxiu-Beichuan faults, outcrops are mainly Neoproterozoic basement rocks (the Pengguan and Baoxing massifs). West of the Wenchuan-Maoxian fault, Neoproterozoic basement rocks are exposed mainly in the Xuelongbao and Tonghua massifs (Fig. 2). These basement rocks are surrounded by strongly folded, faulted and metamorposed Paleozoic sedimentary strata. It is worth noting that late Triassic amphibolite facies metamorphic rocks developed around the Xuelongbao and Tonghua massifs, west of Wenchuan-Maoxian fault. Peak metamorphic conditions were estimated as 10-11 kbar, 530-600 ${ }^{\circ} \mathrm{C}$ [Dirks et al., 1994; Worley and Wilson,1996; Airaghi et al., 2017, 2019], implying that these rocks were exhumed from depths $>30 \mathrm{~km}$ during Mesozoic-Cenozoic time [Worley and Wilson,1996; Airaghi et al., 2017; Zhao et al., 2018]. Farther west, the Songpan-Ganze terrane is composed of a thick $(>8-10 \mathrm{~km})$ sequence of strongly folded Triassic flysch deposits [Chang, 2000; Roger et al., 2008; Ding et al., 2013], intruded by late Triassic-Jurassic granitoids and a few Miocene plutons [Roger et al., 1995]. To the east, the foreland Sichuan Basin consists of $>8 \mathrm{~km}$ of late Triassic-Quaternary terrestrial deposits [SBGMR, 1991; Guo et al., 1996; Li et al., 2003]. In contrast to the thick ( $>7 \mathrm{~km})$ and widespread Mesozoic strata, Cenozoic strata are limited to a total thickness of $<1.5 \mathrm{~km}$ and only locally developed in the southwestern part of the basin [SBGMR, 1991; Burchfiel et al., 1995; Guo et al., 1996].

The Longmen Shan experienced multiple phases of intra-continental deformation during Mesozoic-Cenozoic time [e.g., Burchfiel et al., 1995; Yan et al., 2011]. Mesozoic intra-continental east-verging shortening accommodated transpressional convergence between the Songpan-Ganze terrane and the Yangtze Block (Fig. 2) [SBGMR, 1991; Chen et 
al., 1995]. This Mesozoic orogenic event is documented by several lines of evidence including the development of a coeval foreland basin in the Sichuan Basin [SBGMR, 1991; Chen et al., 1995; Li et al., 2003], late Trassic magmatism in the Songpan-Ganze terrane [Zhang et al., 2006; Xiao et al., 2007] and metamorphic events along the Longmen Shan [Worley and Wilson, 1996; Airaghi et al., 2017, 2019]. In the Late Cretaceous, the Longmen Shan hinterland experienced a phase of top-to-the-NW shear, resulting from the development of a duplex in the middle and upper crust [Tian et al., 2016]. Cenozoic deformation is considered to have reactivated and cut these earlier structures in response to the northward indentation of India into Eurasia Block [e.g., Burchfiel et al., 1995; Yan et al., 2011]. Cenozoic deformation is characterized by east-verging shortening with a minor component of right-lateral faulting, as shown by structural observations [Burchfiel et al., 1995; Feng et al., 2016; Tian et al., 2016] and long- and short-term spatial denudation [Liu-Zeng et al., 2011; Tian et al., 2013].

Rocks exposed in the Xuelongbao massif, the study area, are Neoproterozoic tonalites and granodiorite (Fig. 3) [Zhou et al., 2006]. Peak elevations of the massif exceed $5300 \mathrm{~m}$, whereas river valleys of the Min River drainage system that incise the massif have cut deeply down to elevations of $<1200 \mathrm{~m}$, forming a regional topographic relief of more than $4000 \mathrm{~m}$ (Fig. 1c). The study area is located in the hanging wall of the Wenchuan-Maoxian fault, whose footwall is occupied by the Pengguan massif of Neoproterozoic basement.

\section{Previous Thermochronological Studies}

Several thermochronological studies have been undertaken to constrain the Cenozoic deformation and rock exhumation history of the Longmen Shan and adjacent areas (Fig. 1b). Most previous thermochronology studies in the area focused on the Pengguan massif. Arne et al. [1997] applied a combination of AFT, ZFT and muscovite ${ }^{40} \mathrm{Ar} /{ }^{39} \mathrm{Ar}$ dating techniques to samples from the Longmen Shan, and suggested two phases of cooling in early Cretaceous ( 119-131 Ma) and Miocene ( 20 Ma). Kirby et al. [2002] reported AHe, ZHe, biotite ${ }^{40} \mathrm{Ar} /{ }^{39} \mathrm{Ar}$ and K-feldspar ${ }^{40} \mathrm{Ar}$ release spectra data from several Neoproterozic and Mesozoic granitoids, which indicated that the present high topography of the eastern plateau margin is no older than late Miocene or early Pliocene ( 5-12 Ma). Godard et al. [2009] and Wang et al. 
[2012] applied thermochronology age-elevation plots to the Pengguan massif and provided detailed constraints on the Cenozoic exhumation history. ZHe and AHe vertical profiles of Godard et al. [2009] suggested that a major phase of exhumation commenced between 8 and $11 \mathrm{Ma}$ at a rate of $\sim 0.7 \mathrm{~km} / \mathrm{m}$.y. Wang et al. [2012] applied AHe, AFT, ZHe and ZFT analyses to samples from two vertical profiles located at the eastern and western sides of the Pengguan massif and suggested that the central Longmen Shan may have experienced two phases of rapid rock exhumation at $\sim 30-25 \mathrm{Ma}$ and $\sim 10-0$ Ma with exhumation rates of $\sim 0.8 \mathrm{~km} / \mathrm{m} . \mathrm{y}$. and $\sim 0.4 \mathrm{~km} / \mathrm{m}$.y., respectively. Moreover, Guenthner et al. [2014] applied radiation damage theory to reinterpret previously published ZHe results, which yielded a negative age-eU (effective uranium content) and confirmed a late Cenozoic age for exhumation of the Pengguan massif.

In contrast to the abundant thermochronology studies in the Pengguan massif, few studies have been carried out in the Xuelongbao massif. Godard et al. [2009] reported several ZHe and AHe data from a vertical profile in the northern part of the Xuelongbao massif and suggested that rock exhumation is synchronous with and of a similar rate $(\sim 0.7 \mathrm{~km} / \mathrm{m}$.y.) to that in the Pengguan massif. Tan et al. [2017a] acquired a set of AFT and ZFT ages from a vertical profile in the southern part of the massif and suggested a late Miocene ( 10 Ma) phase of accelerated exhumation at a rate of 0.7-0.9 km/m.y.

Several studies [Xu and Kamp, 2000; Wilson and Fowler, 2011; Li et al., 2012; Cook et al., 2013; Tian et al., 2013] reported thermochronological data from other parts of the Longmen Shan, which are broadly consistent with the results outlined above. Other studies from adjacent areas reported late Miocene [Clark et al., 2005; Enkelmann et al., 2006; Ouimet et al., 2010; Duvall et al., 2012; Tian et al., 2015], Oligocene - middle Miocene [Tian et al., 2013, 2014; Shen et al., 2016; Zhang et al., 2016; Ansberque et al., 2018] or Paleocene to Eocene and Miocene [Liu-Zeng et al., 2018] phases of exhumation with spatially variable exhumation rates (Fig. 1b).

\section{Approach and Methods}

Compared to the abundant thermochronology results from the Pengguan massif, east of the Wenchuan-Maoxian fault, there are few data from the Xuelongbao massif, west of the 
fault (Fig. 3). Therefore, to constrain the exhumation history in the hanging wall of the Wenchuan-Maoxian fault, samples were collected from two vertical transects (Manianping and Caopo) from the central and southern sides of the Xuelongbao massif (Figs. 1c and 3). These two transects were sampled over relief of $\sim 3100 \mathrm{~m}$ (Manianping transect) and $\sim 2600 \mathrm{~m}$ (Caopo transect) within a horizontal distance of $<15 \mathrm{~km}$. The rocks sampled are all granitoids of the Xuelongbao massif (Fig. 3).

AHe, ZHe and ZFT analyses for the Caopo transect were performed at University College London, whereas ZHe analyses for the Manianping transect at The University of Melbourne. Apatite and zircon concentrated for fission-track and (U-Th)/He analysis were extracted using standard crushing, sieving, electromagnetic, and heavy liquid mineral separation techniques. For (U-Th)/He analysis, grains were immersed in ethanol and examined under polarised light to detect possible mineral inclusions and grain dimensions were measured from digital photographs for the calculation of an $\alpha$-ejection correction factor $\left(F_{t}\right)$ [e.g., Farley et al., 1996]. Only good quality euhedral grains, where possible, were selected for analysis. Grains were loaded into Pt capsules and thermally outgassed under vacuum at $\sim 900^{\circ} \mathrm{C}$ for 5 minutes for apatite and $\sim 1300{ }^{\circ} \mathrm{C}$ for 15 minutes for zircon, using a fibre-optically coupled diode laser with $820 \mathrm{~nm}$ wave length. Then, spiked with ${ }^{3} \mathrm{He}$, gas volumes were determined using a Balzers quadrupole mass analyzer. The uncertainty in the sample ${ }^{4} \mathrm{He}$ measurement is estimated at $<1 \%$. Outgassed apatite grains were then spiked with ${ }^{235} \mathrm{U}$ and ${ }^{230} \mathrm{Th}$ and digested at room temperature. For zircon analyses, outgassed grains were first taken out of their Pt capsules and transferred to Parr bombs where they were spiked with ${ }^{233} \mathrm{U}$ and ${ }^{229} \mathrm{Th}$ and digested at $240^{\circ} \mathrm{C}$ for 40 hours in HF. Standard solutions containing the same spike amounts as samples were treated identically, as were a series of unspiked reagent blanks. A second bombing in $\mathrm{HCl}$ for 24 hours at $200^{\circ} \mathrm{C}$ ensured dissolution of fluoride salts and final solutions were diluted to $10 \%$ acidity for analysis on a Varian quadrupole ICP-MS. For single zircon crystals digested in small volumes (0.3-0.5 ml), $\mathrm{U}$ and Th isotope ratios were measured to a precision of $<2 \%$. Unless otherwise indicated, apparent ZHe ages were calculated and corrected for $\alpha$-emission following the approach of Farley et al. [1996]. Durango apatite and Fish Canyon Tuff zircons were run as reference standards with each 
batch of samples analyzed and served as an additional check on analytical accuracy. Based on the standards, we estimated a precision of $\sim 6 \%$ or less at $\pm 1 \sigma$, which incorporates the $\alpha$-correction-related constituent and considers an estimated $5 \mu \mathrm{m}$ uncertainty in grain size measurements, gas analysis and ICP-MS analytical uncertainties.

Samples for FT analysis were mounted on PTFE Teflon and then polished. Fission tracks in zircon are revealed by chemical etching using a binary eutectic of $\mathrm{KOH}: \mathrm{NaOH}$ at $\sim 225^{\circ} \mathrm{C}$ for $\sim 60$ hours. The external detector method was used for age determinations, with Brazil Ruby muscovite attached to the polished mounts to record induced tracks. Neutron irradiations were carried out in the Forschungsneutronenquelle Heinz Maier-Leibnitz (FRM II) research reactor at Garching, Germany, using a fishing line setup. Thermal neutron fluence was monitored by measuring track densities in muscovite plates attached to the Corning-2 standard glass. Following irradiation, muscovite detectors were etched for 20 minutes in $48 \% \mathrm{HF}$ at room temperature to reveal induced tracks. Fission-track densities were measured using an optical microscope at $1250 \times$ magnification with an oil objective. Ages $( \pm 1 \sigma)$ were calibrated by the zeta method [Hurford and Green, 1983], using a zeta factor of $127 \pm 5$ determined by multiple analyses of zircon age standards.

To facilitate the comparison of our results with existing results, our calculation of exhumation rates utilized the age-elevation regression method, as used in previous studies in the region [Godard et al., 2009; Wang et al., 2012; Tan et al., 2017a], and a 3D thermo-kinematic modeling approach that considers heat advection during rock exhumation [Braun 2003; Braun et al., 2012].

\section{Results}

ZFT, ZHe and AHe data from the Caopo and Manianping transects show a strong positive relationship with elevation (Fig. 4). Six ZFT ages obtained from the Caopo transect (2500 m to $4312 \mathrm{~m}$ ) range between 6.1 $\pm 0.7 \mathrm{Ma}$ and $9.0 \pm 0.5 \mathrm{Ma}$ (Tables 1 and 2 and Fig. 4a). The age elevation plot shows an apparent rock exhumation of $\sim 0.5+0.2 /-0.3 \mathrm{~km} / \mathrm{m}$.y. between $\sim 10$ and $\sim 6$ Ma. 
ZHe ages from the Caopo transects are mostly reproducible for each sample (Tables 1 and 3 and Fig. 4b). Plots of ZHe ages versus grain size and effective Uranium ([eU] = [U] + $0.235 \times[\mathrm{Th}])$ content show no clear relationship (Figs. S1 and S2), and therefore radiation damage does not appear to be controlling the distribution of ages [Guenthner et al., 2013]. Regression between the weighted mean ages and elevations indicates exhumation rates of $\sim 1.5+0.3 /-0.6 \mathrm{~km} / \mathrm{m}$.y. between $\sim 7$ and $\sim 5$ Ma (Fig. 4a), three times that between $\sim 9$ and $\sim 6$ Ma constrained by ZFT results.

Over-dispersion in AHe ages has been observed for two out of the eight samples from the Caopo transect (Table 4 and Fig. 4a). However, these AHe outliers do not show clear relationships with eU and grain size (Figs. S1 and S2), indicating potential influences from effects, such as U-Th-zoning, grain breakage [e.g., Fitzgerald et al., 2006; Brown et al., 2013]. Excluding outliers, the calculated weighted mean AHe ages range from $4.1 \pm 0.2$ to $2.4 \pm 0.1$ Ma and show a correlation with elevation. The best-fit line gives an exhumation rate of $\sim 1.4$ $+0.8 /-0.4 \mathrm{~km} / \mathrm{m}$.y between $\sim 4$ and $\sim 2$ Ma (Fig. 4a), consistent with the ZHe rate.

To confirm the rock exhumation rates from the Caopo transect, ZHe data were also acquired for the Manianping transects (Tables 1 and 3 and Fig. 4b). The results also show over-dispersion for a few samples, especially the upper samples, XLB16-21 and XLB16-23, from elevations of $\sim 4922 \mathrm{~m}$ and $4300 \mathrm{~m}$, respectively. Nevertheless, all ages from this transect show a positive correlation with elevation and can be used to calculate an exhumation rate. Regression between ZHe ages and elevations indicates an exhumation rate of $\sim 1.5+0.4 /-0.7 \mathrm{~km} / \mathrm{m}$.y. between $\sim 7$ and $\sim 5 \mathrm{Ma}$, which is similar to rates obtained from the Caopo transect.

\section{3D thermo-kinematic modeling}

To combine the multi-thermochronologic results and to verify the estimates of exhumation rates from the age-elevation profiles, 3D thermo-kinematic modeling was conducted using the Pecube code [Braun 2003; Braun et al., 2012]. The program uses a Bayesian approach (the Neighbourhood Algorithm of Sambridge 1999a, b) to derive estimates of rock uplift rate and topographic relief evolution through time using a three-dimensional thermo-kinematic model that solves the heat equation taking into account 
heat conduction, advection and production under a time-evolving surface topography, which is simplified as a fraction factor $(\mathrm{R})$ of the present topography.

Pecube inverse modelling includes two stages. A first stage, where the NA explores the transdimensional parameter space to find a parameter combination that produces the minimum misfit between the observed data and Pecube predictions. The parameterisation using this space searching method converges quickly in several to a few tens of thousands of iterations [e.g. Braun et al., 2013; Coutand et al., 2014; Herman et al., 2010; Robert et al., 2011]. The forward model results from the first stage are then appraised using the NA-bayesian method [Sambridge, 1999b], which calculates the posterior probability density function (PPDF) of model parameters. For details of the modeling method, see Braun et al. [2012].

\subsection{Model setup}

Modeling used all weighted mean and central AHe, ZHe and ZFT results derived from the 12 samples from the Caopo and Manianping transects. The model setup is shown in Table 5 and Fig. 5. The starting time of the model is set as $20 \mathrm{Ma}$, because previous studies suggested that exhumation in the region may have initiated in early Miocene time [Wang et al., 2012]. Cenozoic faults are absent within the Xuelongbao massif (Fig. 3) and thus are not considered in our modeling of thermochronology data from the massif. Inverted parameters include: (1) a transitional time between 1 and $18 \mathrm{Ma}$, when rock exhumation may have changed, as shown by previous studies in adjacent areas [Godard et al., 2009; Wang et al., 2012], (2) exhumation rates (E1 and E2, varying from 0-3 km/m.y.) before and after the transitional time, $(3)$ a relief factor $(\mathrm{R}, 0.5-1.5)$ that defines the ratio between the transitional time and present-day relief, and (4) basal temperature at $\sim 30 \mathrm{~km}$. The present temperature in the Longmen Shan and farther west area is about $20-30{ }^{\circ} \mathrm{C} / \mathrm{km}$, as shown by borehole thermal logging results [Xu et al. 2010; $\mathrm{Li}$ et al. 2015]. The initial geothermal gradient should be lower than the present-day, because late Cenozoic exhumation should have increased the thermal gradient to the current values [Ehlers, 2005]. Therefore, the parameter space for basal temperature is set as between 400 and $700{ }^{\circ} \mathrm{C}$, which is equivalent to an initial geothermal gradient of $\sim 13-23{ }^{\circ} \mathrm{C} / \mathrm{km}$. We also ran a second model with the basal temperature set as 
400-900 ${ }^{\circ} \mathrm{C}$ to test the sensitivity of models to this parameter (Fig. S3). Other parameters are the same as the first model (Table 5).

Calculations of AHe, ZHe and ZFT ages are based on diffusion and annealing models of Farley [2000], Reiners et al. [2004] and Rahn et al. [2004]. The misfit function is calculated by comparing the slope of the age-elevation relationship for each system. For inverse modeling, 200 iterations, with 100 sample size per iteration and 90\% resampling rate, were applied.

\subsection{Modeling results}

Inverse modeling indicates the transitional time as before $\sim 12-15 \mathrm{Ma}$, with a best-fit at 13 Ma (Figs. 6b). Exhumation rates (E1 and E2) before and after the transitional time are constrained as $<0.5 \mathrm{~km} / \mathrm{m}$.y. and $\sim 0.9-1.2 \mathrm{~km} / \mathrm{m}$.y. (Fig. 6c). These rates overlap with those constrained by age-elevation profiles (Fig. 4). The relief ratio (R) is constrained as $<0.8$ at the transitional time (Fig. 6a), indicating a relief growth since that time. The basal temperature is constrained as $>600{ }^{\circ} \mathrm{C}$ (Fig. 6a), corresponding to an initial geothermal gradient of $>20^{\circ} \mathrm{C} / \mathrm{km}$.

Worth noting is that the inverted relief ratio and basal temperature values with low misfit are distributed close to margins of the prior parameter space (Fig. 6a), as also shown by previous modeling of this kind [van der Beek et al., 2010; Braun et al., 2012]. Such a modeling result is also shown by the second model which enlarges the basal temperature prior space to $400-900{ }^{\circ} \mathrm{C}$ (Fig. S3a). We suggest that these kinds of outputs are modeling artifacts, which arise for deriving better fits to the observations. Nevertheless, other inverted parameter values of the second model (Fig. S3) are similar to those derived for the first model (Fig. 6).

Further, as shown in Fig. 5b, the upper crustal geothermal gradient increased during rock exhumation. The predicted temperature profile of the model with an initial basal temperature of $400-700{ }^{\circ} \mathrm{C}$ yields a current geothermal gradient of $\sim 30-40{ }^{\circ} \mathrm{C} / \mathrm{km}$, falling at the high end of borehole measurements $\left(20-35{ }^{\circ} \mathrm{C} / \mathrm{km}\right)$ [Xu et al. 2011; Li et al. 2015]. Given that the model also provides a reasonable fit to the thermochronology data (Fig. 6d), we prefer the first model and its results. 
To summarize, our new thermochronology results and 3D thermo-kinematic modeling provide unique constraints on rock exhumation rates in the Xuelongbao massif over different time intervals due to differences in closure temperatures (ZFT $>\mathrm{ZHe}>\mathrm{AHe}$, e.g., Reiners and Brandon, 2006), and suggest an enhanced late Miocene exhumation at a rate of $\sim 0.9-1.2$ $\mathrm{km} / \mathrm{m}$.y. This new estimate is significantly higher than that determined by previous studies (0.5-0.8 km/m.y. or 0.7-0.9 km/m.y) using ZHe, ZFT and AFT dates derived from vertical profiles at lower elevations [Godard et al., 2009; Tan et al., 2017].

\section{Discussion}

\subsection{Onset time of late Cenozoic rock exhumation}

The age-elevation profiles show rapid rock uplift and exhumation in the Xuelongbao massif existed at or before $\sim 10$ Ma (Fig. 4); whereas modeling suggested an initiation time at 12-15 Ma (Fig. 6). This timing is consistent with studies of adjacent areas (Fig. 1b), such as the Pengguan massif to the east [Kirby et al., 2002; Godard et al., 2009; Wang et al., 2012; Cook et al., 2013], the Western Qinling to the north [Enkelmann et al., 2006], plateau hinterland areas to the west [Tian et al., 2015], and regions farther south [Clark et al., 2005; Ouimet et al., 2010; Zhang et al., 2016]. This confirms that late Miocene enhanced exhumation was contemporaneous across the eastern part of the Tibetan Plateau, similar to other studies [Clark et al., 2005; Enkelmann et al., 2006; Godard et al., 2009; Tian et al., 2015; Tan et al., 2017a]. Such a synchronous phase of exhumation indicates regional late Miocene growth of topographic relief and has important implications for geodynamics in the eastern Tibetan Plateau [e.g., Royden et al., 1997; Tapponnier et al., 2001; Molnar et al., 2010; Wang et al., 2012].

Previous studies reported an Oligocene - early Miocene phase of enhanced exhumation in the Pengguan massif [Wang et al., 2012], directly east of the study area, as well as at several sites to the far south [Shen et al., 2016; Zhang et al., 2016; Liu-Zeng et al., 2018]. But, this phase of exhumation is not recorded by the thermochronology vertical profiles from the 
Xuelongbao massif, even though a similar combination of thermochronology methods as those previous studies has been used. Furthermore, available thermochronology data with higher closure temperature (e.g., muscovite Ar-Ar data reported by Arne et al., [1997] and Yan et al., [2008]) are as old as 160-120 Ma (Fig. 7), although it is worth noting that the low-temperature heating steps of the ${ }^{40} \mathrm{Ar} /{ }^{39} \mathrm{Ar}$ age spectra do show relatively younger ages ( 100-50 Ma), probably indicating partial loss of radiogenic Ar during a Cenozoic thermal event. However, the current data cannot provide a quantitative constraint on the timing of this event. Therefore, it remains unclear whether or not the Oligocene - early Miocene phase of rock exhumation affected the Longmen Shan hinterland.

\subsection{Post-late Miocene differential exhumation}

A projection of available thermochronology data across the central part of the Longmen Shan shows evident structural control on horizontal age distribution (Fig. 7). For example, ZHe ages decrease westward from $>200$ Ma to $10-50$ Ma from the footwall to hanging wall of the Yingxiu-Beichuan fault. Farther west, ZHe ages decrease again to 6-10 Ma in the hanging wall of the Wenchuan-Maoxian fault. Similar patterns are also shown by AHe, AFT and ZFT age distributions, indicating higher rates of exhumation in the hanging walls of the Yingxiu-Beichuan and Wenchuan-Maoxian faults, as quantified below.

As estimated using age-elevation relationships and 3D thermo-kinematic modeling, post-late Miocene ( 13-0 Ma) exhumation rate in the hanging wall of the Wenchuan-Maoxian fault is $\sim 0.9-1.2 \mathrm{~km} / \mathrm{m}$.y., which is evidently higher than that in the Pengguan massif, the footwall of the fault (Fig. 8). Using the ZHe age-elevation profile method, Godard et al. [2009] indicated that the average exhumation rate in the Pengguan massif is $0.5-0.8 \mathrm{~km} / \mathrm{m} . \mathrm{y}$. since 8-11 Ma. Wang et al. [2012] using a combination of multiple thermochronological data from vertical profiles across the massif, suggested an episodic exhumation history, with rates of $\sim 0.8 \mathrm{~km} / \mathrm{m}$.y. between 30-25 Ma and $\sim 0.3-0.5 \mathrm{~km} / \mathrm{m}$.y. between $10 \mathrm{Ma}$ and the present. 
Compared to the Xuelongbao massif exhumation rate ( 0.9-1.2 km/m.y.), post-late Miocene differential exhumation can be approximated as $\sim 0.6 \mathrm{~km} / \mathrm{m}$.y. for the Wenchuan-Maoxian fault. This estimate is consistent with, but not necessarily related to, the observation that relatively higher metamorphic grade rocks are exposed in the hanging wall of the Wenchuan-Maoxian fault compared to the footwall (amphibolite-greenschist versus zeolite facies) [Dirks et al., 1994; Worley and Wilson,1996; Airaghi et al., 2017, 2019].

\subsection{Fault kinematics}

The spatial exhumation pattern across the Wenchuan-Maoxian fault characterized by apparently higher rates in the hanging wall than the footwall (Fig. 8), indicates that the fault experienced significant movement related to east-vergent reverse faulting. If the topography on both sides of the Wenchuan-Maoxian fault was similar during the late Miocene, the observed differential exhumation rates across the fault ( $\sim .6 \mathrm{~km} / \mathrm{m} . \mathrm{y}$.$) provide a constraint on$ the long-term (million-year scale) throw rate along the fault. Further, because the fault NW-ward dip-angle is as high as $80-90^{\circ}$ [e.g. Liu et al., 1994; Feng et al., 2016], the total dip-slip is similar to the throw rate. Furthermore, as shown by deflection of river channels, strike-slip along the Wenchuan-Maoxian fault could be significant but unknown [Burchfiel et al., 1995; Godard et al., 2010]. For these reasons, the estimate of shortening ( 0.6 km/m.y.) from thermochronolgy data should be considered as a minimum constraint of fault slip rate.

A second possible, but unlikely explanation, for the higher exhumation rates in the Xuelongbao massif is that it is located over a fault-ramp, whereas the Pengguan massif over a flat. However, such a fault geometry is inconsistent with previous geological and geophysical studies that shows the Wenchuan-Maoxian fault as a steeply NW-dipping fault (see Section 2 for details).

Therefore, for interpreting the observed differential exhumation across the fault we prefer a model indicating that the Wenchuan-Maoxian fault has accommodated significant 
dip-slip ( $0.6 \mathrm{~km} / \mathrm{m} . \mathrm{y}$ ). This model is also consistent with medium-short-term observations. For example, several late Pleistocene fluvial terraces (dated at 20-24 kyr by the radiocarbon and thermoluminescence dating methods) were uplifted above the Minjiang riverbed by $\sim 20-50 \mathrm{~m}$ along the Wenchun-Maoxian fault, suggesting a minimum medium-term throw rate of 0.5-1.1 mm/yr [Ma et al., 2005; Li et al., 2006; Zhou et al., 2006; Chen et al., 2007; Godard et al., 2010; Wang et al., 2016, 2017], consistent with the above long-term estimate. Therefore, our data clearly indicate that the slip rate of the Wenchuan-Maoxian fault has remained essentially consistent over a $10^{5}-10^{6}$ yr timescale, implying that this fault has continuously accommodated significant amounts of shortening since the late Miocene to the present.

\subsection{Regional geodynamic implications}

Our new results serve to highlight the importance of the Wenchuan-Maoxian fault in accommodating crustal shortening in the Longmen Shan region and challenge previous interpretations that suggested the fault has accommodated little dip-slip [Godard et al., 2009, 2010; Gao et al., 2016] or acted as a normal fault during the late Cenozoic [Meng et al., 2006; Burchfiel et al., 2008; Royden et al., 2008]. This work provides new support to geodynamic models that predict crustal shortening along the hinterland fault of Longmen Shan [Hubbard and Shaw, 2009; Guo et al., 2013; Tian et al., 2013, 2015; Feng et al., 2016].

Previous geodynamic models for explaining the deformation and uplift of the eastern margin of Tibetan Plateau include a upper crustal shortening model [Hubbard and Shaw, 2009; Tian et al., 2013; Feng et al., 2016; Tan et al., 2019], a lower crustal flow model [Burchfiel et al., 1995, 2008; Royden et al., 1997, 2008; Clark and Royden, 2000], and lithospheric simple-shear or pure-shear deformation models [Robert et al., 2010; Yin, 2010; Guo et al., 2013; Tan et al., 2019]. First, our results, showing crustal shortening in the Longmen Shan hinterland, is consistent with the upper crustal shortening model that highlights the importance of listric reverse faulting in forming the plateau margin [Hubbard and Shaw, 2009; Tian et al., 2013; Feng et al., 2016; Tan et al., 2019]. Second, the transpressional deformation 
along the Wenchuan-Maoxian fault is contrary to the prediction of the lower crustal flow model that the fault was a late Miocene normal fault to accommodate inflation and extrusion of lower crustal in the footwall [Burchfiel et al., 1995, 2008; Royden et al., 1997, 2008; Clark and Royden, 2000]. Lastly, our results cannot provide diagnostic insights on the potential pure-shear deformation at depth. Nevertheless, significant upper curtal shortening in a simple-shear mode is required to explain the previous and our new thermochronology data in the Longmen Shan. To summarize, this study underlines the importance of thrusting-induced crustal shortening in contributing the mountain building in the eastern margin of Tibetan Plateau.

\section{Conclusions}

(1) New low temperature thermochronology data acquired from two vertical profiles spanning the entire relief of the hanging wall of the ESE-verging hinterland Wenchuan-Maoxian fault indicate rapid exhumation since the late Miocene, with accelerated rates of $\sim 0.9-1.2 \mathrm{~km} / \mathrm{m}$.y. since late Miocene time. Such an exhumation rate is significantly higher than that in the footwall ( 0.3-0.5 km/m.y.), indicating a significant difference in exhumation rate across the fault.

(2) The variation in exhumation provides the first and minimum constraint on the long-term dip-slip rate of the Wenchuan-Maoxian fault. This result suggests that the hinterland fault has accommodated significant crustal shortening during late Cenozoic time, even though it was not ruptured by the destructive 2008 Wenchuan Earthquake.

(3) Our results lend support to geodynamic models that highlight crustal shortening as dominating deformation along the eastern Tibetan Plateau.

\section{Acknowledgments}

Funding for this research was provided by National Natural Science Foundation of China (NSFC) grants (no. 41772211 and U1701641), the Guangdong Province Introduced Innovative R\&D Team (2016ZT06N331) and research grants from Institute of Crustal Dynamics, China Earthquake Administration (no. ZDJ2017-24). The University of Melbourne Thermochronology Laboratory receives infrastructure support under the AuScope 
program of the National Collaborative Research Infrastructure Strategy (NCRIS).

Constructive reviews by Peter DeCelles, Devon Orme and an anonymous reviewer as well as editorial work by Paul Tregoning are gratefully acknowledged. The data for this paper are included in the manuscript and the associated supporting information and archived in the Figshare platform (https://figshare.com/s/9c242e2f9d74e8485bd4).

\section{References:}

Airaghi, L., E. Janots, P. Lanari, D. S. Julia, and V. Magnin (2019), Allanite Petrochronology in Fresh and Retrogressed Garnet-Biotite Metapelites from the Longmen Shan (Eastern Tibet), Journal of Petrology, 60(1), 151-176, doi:10.1093/petrology/egy109.

Airaghi, L., P. Lanari, J. de Sigoyer, and S. Guillot (2017), Microstructural vs compositional preservation and pseudomorphic replacement of muscovite in deformed metapelites from the Longmen Shan (Sichuan, China), Lithos, 282-283, 262-280, doi:https://doi.org/10.1016/j.lithos.2017.03.013.

Ansberque, C., V. Godard, V. Olivetti, O. Bellier, J. de Sigoyer, M. Bernet, K. Stübner, X. Tan, X. Xu, and T. A. Ehlers (2018), Differential exhumation across the Longriba Fault System: implications for the eastern Tibetan Plateau, Tectonics, 37, 1-17.

Arne, D., B. Worley, C. Wilson, S. F. Chen, D. Foster, Z. L. Luo, S. G. Liu, and P. Dirks (1997), Differential exhumation in response to episodic thrusting along the eastern margin of the Tibetan Plateau, Tectonophysics, 280(3-4), 239-256.

Braun, J. (2003), Pecube: a new finite-element code to solve the 3D heat transport equation including the effects of a time-varying, finite amplitude surface topography, Comput. Geosci., 29(6), 787-794.

Braun, J., F. Deschamps, D. Rouby, and O. Dauteuil (2013), Flexure of the lithosphere and the geodynamical evolution of non-cylindrical rifted passive margins: Results from a numerical model incorporating variable elastic thickness, surface processes and 3D thermal subsidence, Tectonophysics, 604, 72-82, doi:https://doi.org/10.1016/j.tecto.2012.09.033.

Braun, J., P. van der Beek, P. Valla, X. Robert, F. Herman, C. Glotzbach, V. Pedersen, C. Perry, T. Simon-Labric, and C. Prigent (2012), Quantifying rates of landscape evolution and tectonic processes by thermochronology and numerical modeling of crustal heat transport using PECUBE, Tectonophysics, 524-525, 1-28, doi:10.1016/j.tecto.2011.12.035.

Braun, J., P. van der Beek, P. Valla, X. Robert, F. Herman, C. Glotzbach, V. Pedersen, C. Perry, T. Simon-Labric, and C. Prigent (2012), Quantifying rates of landscape evolution and tectonic processes by thermochronology and numerical modeling of crustal heat transport using PECUBE, Tectonophysics, 524-525, 1-28, doi:https://doi.org/10.1016/j.tecto.2011.12.035.

Brown, R. W., R. Beucher, S. Roper, C. Persano, F. Stuart, and P. Fitzgerald (2013), Broken crystals, Part 1: Theoretical basis and implications for the apatite (U-Th)/He thermochronometer, Geochmica Et Cosmochimica Acta, 122(6), $478-497$.

Burchfiel, B. C., L. H. Royden, R. D. van der Hilst, B. H. Hager, Z. Chen, R. W. King, C. Li, J. Lü, H. Yao, and E. Kirby (2008), A geological and geophysical context for the Wenchuan earthquake of 12 May 2008, Sichuan, People's Republic of China, GSA today, 18(7), 4-11.

Burchfiel, B., Z. Chen, Y. Liu, and L. Royden (1995), Tectonics of the Longmen Shan and adjacent regions, central China, International Geology Review, 37(8), 661-735.

Chang, E. (2000), Geology and Tectonics of the Songpan-Ganzi Fold Belt, Southwestern China, International Geology Review, 42(9), 813-831.

Chen, G., F. Ji, R. Zhou, and J. Xu (2007), Primary research of activity segmentation of Longmen Shan fault zone since late-Quaternary, Seismology and Geology, 29(3), 657-673.

Chen, S., C. J. L. Wilson, and B. A. Worley (1995), Tectonic transition from the Songpan-Garze Fold Belt to the Sichuan Basin, south-western China, Basin Research, 7(3), 235-253.

Chen, Z., B. C. Burchfiel, Y. Liu, R. W. King, L. H. Royden, W. Tang, E. Wang, J. Zhao, and X. Zhang (2000), Global Positioning System measurements from eastern Tibet and their implications for India/Eurasia intercontinental deformation, Journal of Geophysical Research: Solid Earth, 105(B7), 16215-16227. 
Clark, M. K., and L. H. Royden (2000), Topographic ooze: Building the eastern margin of Tibet by lower crustal flow, Geology, 28(8), 703-706.

Clark, M. K., M. A. House, L. H. Royden, K. X. Whipple, B. C. Burchfiel, X. Zhang, and W. Tang (2005), Late Cenozoic uplift of southeastern Tibet, Geology, 33(6), 525-528.

Cook, K. L., L. H. Royden, B. C. Burchfiel, Y. H. Lee, and X. Tan (2013), Constraints on Cenozoic tectonics in the southwestern Longmen Shan from low-temperature thermochronology, Lithosphere, 5(4), 393-406.

Coutand, I., D. M. Whipp Jr., D. Grujic, M. Bernet, M. G. Fellin, B. Bookhagen, K. R. Landry, S. K. Ghalley, and C. Duncan (2014), Geometry and kinematics of the Main Himalayan Thrust and Neogene crustal exhumation in the Bhutanese Himalaya derived from inversion of multithermochronologic data, Journal of Geophysical Research: Solid Earth, 119(2), 1446-1481, doi:10.1002/2013jb010891.

Densmore, A. L., M. A. Ellis, Y. Li, R. Zhou, G. S. Hancock, and N. Richardson (2007), Active tectonics of the Beichuan and Pengguan faults at the eastern margin of the Tibetan Plateau, Tectonics, 26(4), TC4005.

Ding, L., D. Yang, F. Cai, A. Pullen, P. Kapp, G. E. Gehrels, L. Zhang, Q. Zhang, Q. Lai, and Y. Yue (2013), Provenance analysis of the Mesozoic Hoh-Xil-Songpan-Ganzi turbidites in northern Tibet: Implications for the tectonic evolution of the eastern Paleo-Tethys Ocean, Tectonics, 32(1), 34-48.

Dirks, P. H. G. M., C. J. L. Wilson, S. Chen, Z. L. Luo, and S. Liu (1994), Tectonic evolution of the NE margin of the Tibetan Plateau; evidence from the central Longmen Mountains, Sichuan Province, China, Journal of Southeast Asian Earth Sciences, 9(1), 181-192, doi:https://doi.org/10.1016/0743-9547(94)90074-4.

Duvall, A. R., M. K. Clark, B. Avdeev, K. A. Farley, and Z. Chen (2012), Widespread late Cenozoic increase in erosion rates across the interior of eastern Tibet constrained by detrital low-temperature thermochronometry, Tectonics, 31(3), TC3014.

Ehlers, T. A. (2005), Crustal Thermal Processes and the Interpretation of Thermochronometer Data, Reviews in Mineralogy and Geochemistry, 58(1), 315-350.

Enkelmann, E., L. Ratschbacher, R. Jonckheere, R. Nestler, M. Fleischer, R. Gloaguen, B. R. Hacker, Y. Q. Zhang, and Y. S. Ma (2006), Cenozoic exhumation and deformation of northeastern Tibet and the Qinling : Is Tibetan lower crustal flow diverging around the Sichuan Basin? Geological Society of America Bulletin, 118(5-6), 651-671.

Farley, K. A. (2000), Helium diffusion from apatite: General behavior as illustrated by Durango fluorapatite, Journal of Geophysical Research: Solid Earth, 105(B2), 2903-2914, doi:10.1029/1999jb900348.

Farley, K. A., R. A. Wolf, and L. T. Silver (1996), The effects of long alpha-stopping distances on (U-Th)/He ages, Geochimica et Cosmochimica Acta, 60(21), 4223-4229.

Feng, S., P. Zhang, B. Liu, M. Wang, S. Zhu, Y. Ran, W. Wang, Z. Zhang, W. Zheng, and D. Zheng (2016), Deep crustal deformation of the Longmen Shan, eastern margin of the Tibetan Plateau, from seismic reflection and Finite Element modeling, Journal of Geophysical Research: Solid Earth, 121, 767-787.

Fitzgerald, P. G., S. L. Baldwin, L. E. Webb, and P. B. O'Sullivan (2006), Interpretation of (U-Th)/He single grain ages from slowly cooled crustal terranes: A case study from the Transantarctic Mountains of southern Victoria Land, Chemical Geology, 225(1), 91-120.

Flowers, R. M., D. L. Shuster, B. P. Wernicke, and K. A. Farley (2007), Radiation damage control on apatite (U-Th)/He dates from the Grand Canyon region, Colorado Plateau, Geology, 35(5), 447-450.

Friedrich, A. M., B. P. Wernicke, N. A. Niemi, R. A. Bennett, and J. L. Davis (2003), Comparison of geodetic and geologic data from the Wasatch region, Utah, and implications for the spectral character of Earth deformation at periods of 10 to 10 million years, Journal of Geophysical Research: Solid Earth, 108(B4), 2199.

Galbraith, R. F., and G. M. Laslett (1993), Statistical models for mixed fission track ages, Nuclear Tracks and Radiation Measurements, 21(4), 459-470.

Gan, W., P. Zhang, Z. Shen, Z. Niu, M. Wang, Y. Wan, D. Zhou, and J. Cheng (2007), Present-day crustal motion within the Tibetan Plateau inferred from GPS measurements, Journal of Geophysical Research, 112, B08416.

Gao, M., G. Zeilinger, X. Xu, X. Tan, Q. Wang, and M. Hao (2016), Active tectonics evaluation from geomorphic indices for the central and the southern Longmenshan rang on the Eastern Tibetan Plateau, China, Tectonics, 35, 1812-1826.

Godard, V., J. Lavé, J. Carcaillet, R. Cattin, D. Bourlès, and J. Zhu (2010), Spatial distribution of denudation in Eastern Tibet and regressive erosion of plateau margins, Tectonophysics, 491(1), 253-274.

Godard, V., R. Pik, J. Lave, R. Cattin, B. Tibari, J. de Sigoyer, M. Pubellier, and J. Zhu (2009), Late Cenozoic evolution of the central Longmen Shan, eastern Tibet: Insight from (U-Th)/He thermochronometry, Tectonics, 28(5), TC5009.

Guenthner, W. R., P. W. Reiners, and Y. T. Tian (2014), Interpreting date-eU correlations in zircon (U-Th)/He datasets: A 
case study from the Longmen Shan, China, Earth and Planetary Science Letters, 403, 328-339, doi:http://dx.doi.org/10.1016/j.epsl.2014.06.050.

Guenthner, W. R., P. W. Reiners, R. A. Ketcham, L. Nasdala, and G. Giester (2013), Helium diffusion in natural zircon: Radiation damage, anisotropy, and the interpretation of zircon (U-Th)/He thermochronology, American Journal of Science, 313(3), 145-198.

Guo, X., R. Gao, G. R. Keller, X. Xu, H. Wang, and W. Li (2013), Imaging the crustal structure beneath the eastern Tibetan Plateau and implications for the uplift of the Longmen Shan range, Earth and Planetary Science Letters, 379(5), 72-80.

Guo, Z., K. Deng, and Y. Han (1996), Formation and Evolution of the Sichuan Basin, Geol. Publ. House, Beijing.

Herman, F., et al. (2010), Exhumation, crustal deformation, and thermal structure of the Nepal Himalaya derived from the inversion of thermochronological and thermobarometric data and modeling of the topography, Journal of Geophysical Research Atmospheres, 115(B6), 1-30, doi:10.1029/2008JB006126.

Hubbard, J., and J. H. Shaw (2009), Uplift of the Longmen Shan and Tibetan plateau, and the 2008 Wenchuan $(\mathrm{M}=7.9)$ earthquake, Nature, 458(7235), 194-197.

Hurford, A. J., and P. F. Green (1983), The zeta age calibration of fission-track dating, Chemical Geology, 41, $285-317$.

Jia, D., G. Wei, Z. Chen, B. Li, Q. Zeng, and G. Yang (2006), Longmen Shan fold-thrust belt and its relation to the western Sichuan Basin in central China: New insights from hydrocarbon exploration, AAPG Bulletin, 90(9), 1425-1447, doi:10.1306/03230605076.

Jin, W., L. Tang, K. Yang, G. Wan, and Z. Lü (2010), Segmentation of the Longmen Mountains thrust belt, Western Sichuan Foreland Basin, SW China, Tectonophysics, 485(1), 107-121, doi:10.1016/j.tecto.2009.12.007.

Kirby, E., P. W. Reiners, M. A. Krol, K. X. Whipple, K. V. Hodges, K. A. Farley, W. Q. Tang, and Z. L. Chen (2002), Late Cenozoic evolution of the eastern margin of the Tibetan Plateau: Inferences from $40 \mathrm{Ar} / 39 \mathrm{Ar}$ and $(\mathrm{U}-\mathrm{Th}) / \mathrm{He}$ thermochronology, Tectonics, 21(1), 1-20.

$\mathrm{Li}$, H., et al. (2013), Characteristics of the fault-related rocks, fault zones and the principal slip zone in the Wenchuan Earthquake Fault Scientific Drilling Project Hole-1 (WFSD-1), Tectonophysics, 584, 23-42.

$\mathrm{Li}, \mathrm{H}$., et al. (2015), Long-term temperature records following the Mw 7.9 Wenchuan (China) earthquake are consistent with low friction, Geology, 43(2), 163-166, doi:10.1130/g35515.1.

Li, Y., P. A. Allen, A. L. Densmore, and Q. Xu (2003), Evolution of the Longmen Shan Foreland Basin (Western Sichuan, China) during the Late Triassic Indosinian Orogeny, Basin Research, 15(1), 117-138.

Li, Y., R. Zhou, A. L. Densmore, and M. A. Ellis (2006), Geomorphic evidence for the late cenozoic strike-sliiping and thrusting in Longmen moutain at the eastern margin of the Tibetan Plateau, Quaternary Sciences, 26(1), 40-51.

Li, Z., S. Liu, H. Chen, B. Deng, M. Hou, W. Wu, and J. Cao (2012), Spatial variation in Meso-Cenozoic exhumation history of the Longmen Shan thrust belt (eastern Tibetan Plateau) and the adjacent western Sichuan basin: Constraints from fission track thermochronology, Journal of Asian Earth Sciences, 47, 185-203.

Liu, H., H. Liang, L. Cai, and S. Fei (2010), Structural Styles of the Longmenshan Thrust Belt and Evolution of the Foreland Basin in Western Sichuan Province, China, Acta Geologica Sinica, 7(4), 351-372.

Liu-Zeng, J., et al. (2009), Co-seismic ruptures of the 12 May 2008, Ms 8.0 Wenchuan earthquake, Sichuan: East-west crustal shortening on oblique, parallel thrusts along the eastern edge of Tibet, Earth and Planetary Science Letters, 286(3), 355-370.

Liu-Zeng, J., et al. (2018), Multiple episodes of fast exhumation since Cretaceous in southeast Tibet, revealed by low-temperature thermochronology, Earth and Planetary Science Letters, 490, 62-76.

Liu-Zeng, J., L. Wen, M. Oskin, and L. Zeng (2011), Focused modern denudation of the Longmen Shan margin, eastern Tibetan Plateau, Geochemistry, Geophysics, Geosystems, 12(11), Q11007, doi:10.1029/2011gc003652.

Lu, R., D. He, S. John, J. E. Wu, B. Liu, and Y. Chen (2014), Structural model of the central Longmen Shan thrusts using seismic reflection profiles: Implications for the sediments and deformations since the Mesozoic, Tectonophysics, 630, 43-53, doi:https://doi.org/10.1016/j.tecto.2014.05.003.

Ludwig, K. (1991), ISOPLOT: A plotting and regression program for radiogenic isotope data; version 2.53, U. S. Geol. Surv. Open File Report, 91-445.

Ma, B., G. Su, Z. Hou, and S. Shu (2005), Late quaternary slip rate in the central part of the Longmen Shan fault zone from terrace defformation along the Minjiang River, Seismology and Geology, 27(2), 234-242.

Meesters, A. G. C. A., and T. J. Dunai (2002), Solving the production-diffusion equation for finite diffusion domains of various shapes: Part II. Application to cases with $\alpha$-ejection and nonhomogeneous distribution of the source, Chemical 
Geology, 186(3), 347-363.

Meng, Q., J. Hu, E. Wang, and H. Qu (2006), Late Cenozoic denudation by large-magnitude landslides in the eastern edge of Tibetan Plateau, Earth and Planetary Science Letters, 243(1-2), 252-267.

Molnar, P., W. R. Boos, and D. S. Battisti (2010), Orographic Controls on Climate and Paleoclimate of Asia: Thermal and Mechanical Roles for the Tibetan Plateau, Annual Review of Earth and Planetary Sciences, 38(1), 77-102, doi:10.1146/annurev-earth-040809-152456.

Murakami, T., B. C. Chakoumakos, R. C. Ewing, G. R. Lumpkin, and W. J. Weber (1991), Alpha-Decay Event Damage in Zircon, American Mineralogist, 76:9-10(9), 1510-1532.

Naito, N., Y. Ageta, S. Iwata, Y. Matsuda, R. Suzuki, Karma, and H. Yabuki (2006), Glacier shrinkages and climate conditions around Jichu Dramo Glacier in the Bhutan Himalayas from 1998 to 2003, Bulletin of Glaciological Research, 23, 51-61.

Niemi, N., and M. K. Clark (2018), Long-term exhumation rates exceed paleoseismic slip rates in the central Santa Monica Mountains, Los Angeles County, California, Geology, 46(1), 63-66.

Ouimet, W., K. Whipple, L. Royden, P. Reiners, K. Hodges, and M. Pringle (2010), Regional incision of the eastern margin of the Tibetan Plateau, Lithosphere, 2(1), 50-63.

Rahn, M., M. Brandon, G. Batt, and J. Garver (2004), A zero-damage model for fission-track annealing in zircon, American Mineralogist, 89, 473-484, doi:10.2138/am-2004-0401.

Ran, Y., L. Chen, J. Chen, H. Wang, G. Chen, J. Yin, X. Shi, C. Li, and X. Xu (2010), Paleoseismic evidence and repeat time of large earthquakes at three sites along the Longmenshan fault zone, Tectonophysics, 491(1), 141-153.

Reiners, P. W., and M. T. Brandon (2006), Using thermochronology to understand orogenic erosion, Annual Review of Earth and Planetary Sciences, 34, 419-466.

Reiners, P. W., T. L. Spell, S. Nicolescu, and K. A. Zanetti (2004), Zircon (U-Th)/He thermochronometry: He diffusion and comparison with ${ }^{40} \mathrm{Ar} /{ }^{39} \mathrm{Ar}$ dating, Geochimica et cosmochimica acta, 68(8), 1857-1887.

Robert, A., M. Pubellier, J. de Sigoyer, J. Vergne, A. Lahfid, R. Cattin, N. Findling, and J. Zhu (2010), Structural and thermal characters of the Longmen Shan (Sichuan, China), Tectonophysics, 491(1), 165-173, doi:https://doi.org/10.1016/j.tecto.2010.03.018.

Robert, X., P. van der Beek, J. Braun, C. Perry, and J.-L. Mugnier (2011), Control of detachment geometry on lateral variations in exhumation rates in the Himalaya: Insights from low-temperature thermochronology and numerical modeling, Journal of Geophysical Research, 116, B05202, doi:10.1029/2010jb007893.

Roger, F. O., M. Jolivet, and J. Malavieille (2008), Tectonic evolution of the Triassic fold belts of Tibet, Comptes Rendus Geosciences, 340(2), 180-189.

Roger, F., S. Calassou, J. Lancelot, J. Malavieille, M. Mattauer, X. Zhiqin, H. Ziwen, and H. Liwei (1995), Miocene emplacement and deformation of the Konga Shan granite (Xianshui He fault zone, west Sichuan, China): Geodynamic implications, Earth and Planetary Science Letters, 130(1), 201-216.

Royden, L. H., B. Burchfiel, R. King, E. Wang, Z. L. Chen, F. Shen, and Y. P. Liu (1997), Surface Deformation and Lower Crustal Flow in Eastern Tibet, Science, 276, 788-790, doi:10.1126/science.276.5313.788.

Royden, L. H., B. C. Burchfiel, and R. D. van der Hilst (2008), The geological evolution of the Tibetan Plateau, Science, 321(5892), 1054.

Sambridge, M. (1999), Geophysical inversion with a neighbourhood algorithm-I. Searching a parameter space, Geophy. J. Int., 138(2), 479-494, doi:10.1046/j.1365-246X.1999.00876.x.

Sambridge, M. (1999), Geophysical inversion with a neighbourhood algorithm-II. Appraising the ensemble, Geophysical Journal International, 138(3), 727-746, doi:10.1046/j.1365-246x.1999.00900.x.

SBGMR (1991), Sichuan Bureau of Geology and Mineral Resources. Regional Geology of Sichuan Province, 728 pp., Geology House, Beijing.

Shen, X., Y. Tian, D. Li, S. Qin, P. Vermeesch, and J. Schwanethal (2016), Oligocene-Early Miocene river incision near the first bend of the Yangze River: Insights from apatite (U-Th-Sm)/He thermochronology, Tectonophysics, 687, $223-231$.

Shen, Z. K., J. Sun, P. Zhang, Y. Wan, M. Wang, R. Bürgmann, Y. Zeng, W. Gan, H. Liao, and Q. Wang (2009), Slip maxima at fault junctions and rupturing of barriers during the 2008 Wenchuan earthquake, Nature Geoscience, 2(10), 718-724.

Shen, Z., J. Lv, M. Wang, and R. Burgmann (2005), Contemporary crustal deformation around the southeast borderland of the Tibetan Plateau, Journal of Geophysical Research, 110(B11409), 1-17.

Tan, X., X. Xu, Y. H. Lee, R. Lu, Y. Liu, C. Xu, K. Li, G. Yu, and W. Kang (2017a), Late Cenozoic thrusting of major faults 
along the central segment of Longmen Shan, eastern Tibet: Evidence from low-temperature thermochronology, Tectonophysics, 712-713, 145-155.

Tan, X., Y. Lee, X. Xu, and K. L. Cook (2017b), Cenozoic exhumation of the Danba antiform, eastern Tibet: Evidence from low-temperature thermochronology, Lithosphere, 9(4), 534-544.

Tan, X., Y. Liu, Y.-H. Lee, R. Lu, X. Xu, J. Suppe, F. Shi, and C. Xu (2019), Parallelism between the maximum exhumation belt and the Moho ramp along the eastern Tibetan Plateau margin: Coincidence or consequence?, Earth and Planetary Science Letters, 507, 73-84, doi:https://doi.org/10.1016/j.epsl.2018.12.001.

Tapponnier, P., Z. Q. Xu, F. Roger, B. Meyer, N. Arnaud, G. Wittlinger, and Y. J.S. (2001), Oblique Stepwise Rise and Growth of the Tibet Plateau, Science, 294(5547), 1671-1677, doi:10.1126/science.105978.

Tian, Y. T., B. P. Kohn, S. B. Hu, and A. J. W. Gleadow (2015), Synchronous fluvial response to surface uplift in the eastern Tibetan Plateau: Implications for crustal dynamics, Geophysical Research Letters, 42(1), 29-35.

Tian, Y., B. P. Kohn, A. J. W. Gleadow, and S. Hu (2013), Constructing the Longmen Shan eastern Tibetan Plateau margin: Insights from low-temperature thermochronology, Tectonics, 32(3), 576-592.

Tian, Y., B. P. Kohn, A. J. W. Gleadow, and S. Hu (2014), A thermochronological perspective on the morphotectonic evolution of the southeastern Tibetan Plateau, Journal of Geophysical Research: Solid Earth, 119(1), 676-698.

Tian, Y., B. P. Kohn, D. Phillips, S. Hu, A. J. W. Gleadow, and A. Carter (2016), Late Cretaceous-earliest Paleogene deformation in the Longmen Shan fold-and-thrust belt, eastern Tibetan Plateau margin: Pre-Cenozoic thickened crust?, Tectonics, 35(10), 2293-2312.

van der Beek, P., P. G Valla, F. Herman, J. Braun, C. Persano, K. Dobson, and E. Labrin (2010), Inversion of thermochronological age-elevation profiles to extract independent estimates of denudation and relief history - II: Application to the French Western Alps, Earth and Planetary Science Letters, 296, 9-22, doi:10.1016/j.epsl.2010.04.032.

Wang, E., E. Kirby, K. Furlong, M. van Soest, G. Xu, X. Shi, P. Kamp, and K. Hodges (2012), Two-phase growth of high topography in eastern Tibet during the Cenozoic, Nature Geoscience, 5(9), 640-645.

Wang, X. (2016), Analysis of the late Quaternary activity along the Wenchuan-Maoxian fault-middle of the back-range fault at the Longmen Shan fault zone. Institute of Geology, China Earthquake Administration. , Master thesis, Institute of Geology, China Earthquake Administration, Beijing.

Wang, X., C. Li, L. Lv, and J. Dong (2017), Analysis of the late Quaternary activity along the Wenchuan-Maoxian fault-middle of the back-range fault at the Longmen Shan fault zone, Seismology and Geology, 39(3), 572-586.

Whipp Jr., D. M., T. A. Ehlers, A. E. Blythe, K. W. Huntington, K. V. Hodges, and D. W. Burbank (2007), Plio-Quaternary exhumation history of the central Nepalese Himalaya: 2. Thermokinematic and thermochronometer age prediction model, Tectonics, 26(3), doi:10.1029/2006tc001991.

Wilson, C. J. L., and A. P. Fowler (2011), Denudational response to surface uplift in east Tibet: Evidence from apatite fission-track thermochronology, Geological Society of America Bulletin, 123(9-10), 1966-1987.

Worley, B. A., and C. J. L. Wilson (1996), Deformation partitioning and foliation reactivation during transpressional orogenesis, an example from the Central Longmen Shan, China, Journal of Structural Geology, 18(4), 395-411, doi:https://doi.org/10.1016/0191-8141(95)00095-U.

Xiao, L., H. F. Zhang, J. D. Clemens, Q. W. Wang, Z. Z. Kan, K. M. Wang, P. Z. Ni, and X. M. Liu (2007), Late Triassic granitoids of the eastern margin of the Tibetan Plateau: Geochronology, petrogenesis and implications for tectonic evolution, Lithos, 96(3), 436-452, doi:https://doi.org/10.1016/j.lithos.2006.11.011.

$\mathrm{Xu}$, G., and P. J. J. Kamp (2000), Tectonics and denudation adjacent to the Xianshuihe Fault, eastern Tibetan Plateau: Constraints from fission track thermochronology, Journal of Geophysical Research: Solid Earth, 105(B8), 19231-19251.

Xu, M., C. Zhu, Y. Tian, R. Song, and S. Hu (2011), Borehole Temperature Logging and Characteristics of Subsurface Temperature in the Sichuan Basin, Chinese Journal of Geophysics, 54(2), 224-233, doi:10.1002/cjg2.1604.

Xu, M., C. Zhu, Y. Tian, S. Rao, and S. Hu (2011), Borehole temperature logging and characteristics of subsurface temperature in Sichuan Basin, Chin. J. Geophys., 54(4), 1052-1060.

Xu, X., X. Wen, G. Yu, C. Guihua, and Y. Klinger (2009), Co-seismic reverse- and oblique-slip surface faulting generated by the 2008 Mw 7.9 Wenchuan earthquake, China, Geology, 37(6), 515-518.

Xu, Z., L. Hou, Z. Wang, X. Hu, and M. Huang (1992), Orogenic Processes of the Songpan-Garzê Orogenic Belt of China, 190 pp., Geol. Publ. House,, Beijing.

Xue, Z., G. Martelet, W. Lin, M. Faure, Y. Chen, W. Wei, S. Li, and Q. Wang (2017), Mesozoic Crustal Thickening of the Longmenshan Belt (NE Tibet, China) by Imbrication of Basement Slices: Insights From Structural Analysis, Petrofabric 
and Magnetic Fabric Studies, and Gravity Modeling, Tectonics, 36(12), 3110-3134, doi:10.1002/2017tc004754.

Yan, D., M. Zhou, G. Wei, J. Gao, S. Liu, P. Xu, and X. Shi (2008), The Pengguan tectonic dome of Longmen Mountains, Sichuan Province: Mesozoic denudation of a Neopro-terozoic magmatic arc-basin system, Science in China Series D-Earth Sciences, 51(11), 1545.

Yan, D., M. Zhou, S. Li, and G. Wei (2011), Structural and geochronological constraints on the Mesozoic-Cenozoic tectonic evolution of the Longmen Shan thrust belt, eastern Tibetan Plateau, Tectonics, 30(6), TC6005.

Yan, D., Y. Zhou, L. Qiu, M. Wells, H. Mu, and C. Xu (2018), The Longmenshan Tectonic Complex and adjacent tectonic units in the eastern margin of the Tibetan Plateau: A review, Journal of Asian Earth Sciences, 164, 33-57, doi:10.1016/j.jseaes.2018.06.017.

Yin, A. (2010), A special issue on the great 12 May 2008 Wenchuan earthquake (Mw7.9): Observations and unanswered questions, Tectonophysics, 491(1), 1-9, doi:https://doi.org/10.1016/j.tecto.2010.05.019.

Zhang, H. F., L. Zhang, N. Harris, L. L. Jin, and H. L. Yuan (2006), U-Pb zircon ages, geochemical and isotopic compositions of granitoids in Songpan-Garze fold belt, eastern Tibetan Plateau: constraints on petrogenesis and tectonic evolution of the basement, Contrib Mineral Petrol, 152(1), 75-88, doi:10.1007/s00410-006-0095-2.

Zhang, H., M. E. Oskin, J. Liu-Zeng, P. Zhang, P. W. Reiners, and P. Xiao (2016), Pulsed exhumation of interior eastern Tibet: Implications for relief generation mechanisms and the origin of high-elevation planation surfaces, Earth and Planetary Science Letters, 449, 176-185.

Zhang, P. (2013), A review on active tectonics and deep crustal processes of the Western Sichuan region, eastern margin of the Tibetan Plateau, Tectonophysics, 584, 7-22.

Zhang, P., X. Wen, Z. Shen, and J. Chen (2010), Oblique, High-Angle, Listric-Reverse Faulting and Associated Development of Strain: The Wenchuan Earthquake of May 12, 2008, Sichuan, China, 5th international symposium on the tibetan plateau 24th himalaya-karakorum-tibet workshop, 353-382.

Zhang, Y., A. Replumaz, P. H. Leloup, G. Wang, M. Bernet, P. van der Beek, J. L. Paquette, and M. L. Chevalier (2017), Cooling history of the Gongga batholith: Implications for the Xianshuihe Fault and Miocene kinematics of SE Tibet, Earth and Planetary Science Letters, 465, 1-15.

Zhang, Y., et al. (2015), Timing and rate of exhumation along the Litang fault system, implication for fault re-organisation in South East Tibet, Tectonics, 34(6), 1219-1243.

Zhao, G., M. J. Unsworth, Y. Zhan, L. Wang, X. Chen, A. G. Jones, J. Tang, Q. Xiao, J. Wang, and J. Cai (2012), Crustal structure and rheology of the Longmenshan and Wenchuan Mw 7.9 earthquake epicentral area from magnetotelluric data, Geology, 40(12), 1139-1142.

Zhao, Z. B., J. X. Du, F. H. Liang, C. Wu, and X. J. Liu (2019), Structure and Metamorphism of Markam Gneiss Dome From the Eastern Tibetan Plateau and Its Implications for Crustal Thickening, Metamorphism, and Exhumation, Geochemistry, Geophysics, Geosystems, 20(1), 24-45, doi:10.1029/2018gc007617.

Zhou, M., D. Yan, C. Wang, L. Qi, and A. Kennedy (2006), Subduction-related origin of the 750 Ma Xuelongbao adakitic complex (Sichuan Province, China): implications for the tectonic setting of the giant Neoproterozoic magmatic event in South China, Earth and Planetary Science Letters, 248(1), 286-300.

Zhou, R., Y. Li, A. L. Densmore, M. A. Ellis, Y. He, F. Wang, and X. Li (2006), Active tectonics of the eastern margin of the Tibet Plateau, Journal Mineral Petrology, 26(2), 40-51. 


\section{Tables:}

Table 1. Summary of new AHe, ZHe and ZFT data reported in this study.

\begin{tabular}{|c|c|c|c|c|c|c|c|c|c|}
\hline Sample No. & Latitude & Longitude & Elevation & AHe age $^{1}$ & $1 \sigma$ & ZHe age $^{1}$ & $1 \sigma$ & ZFT age & $1 \sigma$ \\
\hline \multicolumn{10}{|c|}{ Caopo transect } \\
\hline XLB16-11 & 31.4089 & 103.3620 & 4312 & 4.1 & 0.2 & 7.0 & 0.2 & 8.3 & 0.8 \\
\hline XLB16-13 & 31.4049 & 103.3563 & 4056 & 3.0 & 0.4 & 5.9 & 0.5 & 9.0 & 0.6 \\
\hline XLB16-16 & 31.4058 & 103.3435 & 3683 & 3.9 & 0.1 & 6.6 & 0.2 & 8.9 & 0.6 \\
\hline XLB16-18 & 31.3989 & 103.3319 & 3126 & 3.0 & 0.2 & 6.5 & 0.5 & & \\
\hline BX319 & 31.3935 & 103.3829 & 2905 & & & & & 6.7 & 0.6 \\
\hline BX318 & 31.3801 & 103.3775 & 2700 & 3.6 & 0.3 & 5.9 & 0.5 & 6.2 & 1.0 \\
\hline BX317 & 31.3713 & 103.3807 & 2500 & 2.8 & 0.3 & & & 6.1 & 0.7 \\
\hline BX316 & 31.3498 & 103.3856 & 2107 & 2.5 & 0.1 & 5.4 & 0.4 & & \\
\hline BX321 & 31.3180 & 103.3970 & 1728 & 2.4 & 0.1 & 5.4 & 0.2 & & \\
\hline \multicolumn{10}{|c|}{ Manianping transect } \\
\hline XLB16-21 & 31.4347 & 103.4082 & 4922 & & & 7.1 & 0.5 & & \\
\hline XLB16-23 & 31.4244 & 103.4132 & 4300 & & & 7.2 & 0.7 & & \\
\hline XLB16-25 & 31.4276 & 103.4243 & 3605 & & & 6.2 & 0.7 & & \\
\hline XLB16-3 & 31.4027 & 103.4301 & 2960 & & & 6.4 & 0.3 & & \\
\hline XLB16-5 & 31.4101 & 103.4464 & 2401 & & & 6.0 & 0.3 & & \\
\hline XLB16-7 & 31.4040 & 103.4801 & 1827 & & & 5.4 & 0.6 & & \\
\hline
\end{tabular}

${ }^{1}$ Weighted means calculated using Isoplot V3.59 [Ludwig, 1991].

Table 2. ZFT results from Caopo transect of Xuelongbao massif, central Longmen Shan

\begin{tabular}{|c|c|c|c|c|c|c|c|c|c|c|c|}
\hline \multirow{2}{*}{$\begin{array}{l}\text { Sample } \\
\text { No. }\end{array}$} & \multirow{2}{*}{$\begin{array}{l}\text { No. of } \\
\text { Grains }\end{array}$} & \multicolumn{2}{|c|}{ Spontaneous* } & \multicolumn{2}{|c|}{ Induced* } & \multicolumn{2}{|c|}{ Dosimeter* } & \multirow{2}{*}{$\begin{array}{c}\mathrm{P}\left(\chi^{2}\right) \\
\\
\%\end{array}$} & \multirow{2}{*}{$\begin{array}{c}\mathrm{U} \\
(\mathrm{ppm})\end{array}$} & \multirow{2}{*}{$\begin{array}{c}\text { Age } \\
\text { Dispersion } \\
\%\end{array}$} & \multirow{2}{*}{$\begin{array}{l}\text { Age } \\
(\mathrm{Ma}) \\
( \pm 1 \sigma)^{\dagger}\end{array}$} \\
\hline & & $\rho_{\mathrm{s}}\left(\times 10^{6} \mathrm{~m}^{-2}\right)$ & Ns & $\begin{array}{c}\rho_{\mathrm{i}}\left(\times 10^{6}\right. \\
\left.\mathrm{m}^{-2}\right)\end{array}$ & $\mathrm{N}_{\mathrm{i}}$ & $\rho_{\mathrm{d}}\left(\times 10^{6} \mathrm{~m}^{-2}\right)$ & $\mathrm{N}_{\mathrm{d}}$ & & & & \\
\hline XLB16-11 & 17 & 0.54 & 220 & 2.30 & 965 & 0.58 & 2406 & 15.7 & 142.9 & 18.7 & $\begin{array}{c}8.3 \pm \\
0.8\end{array}$ \\
\hline XLB16-13 & 20 & 0.59 & 275 & 2.31 & 1121 & 0.58 & 2406 & 93.0 & 143.5 & 0 & $\begin{array}{c}9.0 \pm \\
0.6\end{array}$ \\
\hline XLB16-16 & 20 & 1.08 & 282 & 4.39 & 1163 & 0.58 & 2406 & 74.7 & 272.8 & 0.2 & $\begin{array}{c}8.9 \pm \\
0.6\end{array}$ \\
\hline BX319 & 14 & 0.99 & 233 & 5.23 & 1267 & 0.58 & 2406 & 14.1 & 325.2 & 16 & $6.7 \pm 0.6$ \\
\hline BX318 & 4 & 0.58 & 44 & 3.52 & 262 & 0.58 & 2406 & 85.3 & 218.8 & 0 & $6.2 \pm 1.0$ \\
\hline
\end{tabular}


* All samples were dated using the external detector method.

${ }^{\dagger}$ Age data determined by AC using zeta $(\mathrm{CN} 5)=127 \pm 5$. All ages are central ages calculated from Galbraith and Laslett (1993).

Table 3. Single-grain zircon (U-Th)/He results from the Xuelongbao massif, central Longmen Shan

\begin{tabular}{|c|c|c|c|c|c|c|c|c|c|c|c|}
\hline Sample No. & $\begin{array}{l}{ }^{4} \mathrm{He} \\
\text { (ncc) }\end{array}$ & $\begin{array}{l}\text { Mass } \\
(\mathrm{mg})\end{array}$ & $\begin{array}{c}\mathrm{U} \\
(\mathrm{ppm})\end{array}$ & $\begin{array}{c}\text { Th } \\
\text { (ppm) }\end{array}$ & $\mathrm{Th} / \mathrm{U}$ & $\begin{array}{l}\mathrm{Rs}^{1} \\
(\mu \mathrm{m})\end{array}$ & $\mathrm{F}_{\mathrm{T}}{ }^{2}$ & $\begin{array}{l}\text { Corr. } \\
\text { Age } \\
(\mathrm{Ma})\end{array}$ & $\begin{array}{l}\text { Error } \\
( \pm 1 \sigma)\end{array}$ & $\begin{array}{c}\text { Weighted } \\
\text { Mean }^{3} \\
(\mathrm{Ma} \pm 1 \sigma)\end{array}$ & {$[\mathrm{eU}]^{4}$} \\
\hline \multicolumn{12}{|l|}{ Caopo transect } \\
\hline XLB16-11-1 & 3.251 & 0.0114 & 226.4 & 782.3 & 3.5 & 70.7 & 0.81 & 7.1 & 0.5 & $7.0 \pm 0.2$ & 410.2 \\
\hline XLB16-11-2 & 5.920 & 0.0144 & 462.7 & 379.9 & 0.8 & 71.8 & 0.82 & 7.5 & 0.5 & & 552.0 \\
\hline XLB16-11-3 & 5.923 & 0.0123 & 549.2 & 886.5 & 1.6 & 70.4 & 0.81 & 6.5 & 0.4 & & 757.5 \\
\hline XLB16-11-4 & 2.256 & 0.0109 & 215.9 & 381.5 & 1.8 & 65.9 & 0.80 & 7.0 & 0.5 & & 305.5 \\
\hline XLB16-13-1 & 2.408 & 0.0130 & 270.8 & 116.5 & 0.4 & 77.6 & 0.83 & 6.1 & 0.4 & $5.9 \pm 0.5$ & 298.2 \\
\hline XLB16-13-2 & 2.933 & 0.0094 & 407.0 & 332.7 & 0.8 & 68.8 & 0.81 & 6.5 & 0.4 & & 485.2 \\
\hline XLB16-13-3 & 2.123 & 0.0090 & 371.2 & 148.5 & 0.4 & 63.9 & 0.80 & 6.0 & 0.4 & & 406.1 \\
\hline XLB16-13-4 & 1.626 & 0.0094 & 310.0 & 123.7 & 0.4 & 63.0 & 0.80 & 5.2 & 0.3 & & 339.0 \\
\hline XLB16-16-1 & 1.314 & 0.0080 & 229.9 & 151.9 & 0.7 & 54.5 & 0.77 & 6.7 & 0.4 & $6.6 \pm 0.2$ & 265.6 \\
\hline XLB16-16-2 & 1.193 & 0.0068 & 217.0 & 147.6 & 0.7 & 59.8 & 0.79 & 7.3 & 0.5 & & 251.7 \\
\hline XLB16-16-3 & 0.827 & 0.0063 & 191.4 & 125.3 & 0.7 & 55.3 & 0.77 & 6.3 & 0.4 & & 220.8 \\
\hline XLB16-16-4 & 1.148 & 0.0064 & 260.4 & 178.6 & 0.7 & 55.2 & 0.77 & 6.4 & 0.4 & & 302.3 \\
\hline XLB16-18-1 & 1.402 & 0.0077 & 283.9 & 156.0 & 0.5 & 62.0 & 0.79 & 5.9 & 0.4 & $6.5 \pm 0.5$ & 320.6 \\
\hline XLB16-18-2 & 2.887 & 0.0158 & 240.7 & 129.2 & 0.5 & 72.6 & 0.82 & 6.7 & 0.4 & & 271.1 \\
\hline XLB16-18-3 & 2.244 & 0.0089 & 372.1 & 167.9 & 0.5 & 61.0 & 0.79 & 6.4 & 0.4 & & 411.6 \\
\hline XLB16-18-4 & 2.087 & 0.0084 & 312.7 & 141.2 & 0.5 & 58.1 & 0.78 & 7.5 & 0.5 & & 345.9 \\
\hline ВX318-1 & 0.104 & 0.0054 & 165.1 & 90.5 & 0.5 & 58.1 & 0.78 & 6.4 & 0.4 & $5.9 \pm 0.5$ & 186.3 \\
\hline BX318-2 & 0.103 & 0.0049 & 97.5 & 59.4 & 0.6 & 52.4 & 0.76 & 5.2 & 0.3 & & 111.5 \\
\hline ВX318-3 & 0.099 & 0.0105 & 119.4 & 90.6 & 0.8 & 68.5 & 0.80 & 6.4 & 0.4 & & 140.7 \\
\hline BX318-4 & 0.150 & 0.0071 & 477.8 & 234.6 & 0.5 & 57.2 & 0.78 & 6.1 & 0.4 & & 532.9 \\
\hline BX316-1 & 0.702 & 0.0132 & 77.7 & 30.7 & 0.4 & 69.0 & 0.81 & 6.2 & 0.4 & $5.4 \pm 0.4$ & 84.9 \\
\hline BX316-2 & 0.563 & 0.0111 & 81.7 & 32.4 & 0.4 & 72.2 & 0.82 & 5.6 & 0.4 & & 89.3 \\
\hline BX316-3 & 0.560 & 0.0097 & 106.0 & 36.7 & 0.3 & 70.0 & 0.81 & 5.0 & 0.3 & & 114.6 \\
\hline BX316-4 & 0.843 & 0.0172 & 79.5 & 38.9 & 0.5 & 80.9 & 0.84 & 5.4 & 0.3 & & 88.6 \\
\hline BX321-1 & 0.426 & 0.0158 & 391.5 & 226.7 & 0.6 & 76.2 & 0.82 & 5.8 & 0.4 & $5.4 \pm 0.2$ & 444.8 \\
\hline
\end{tabular}




\begin{tabular}{|c|c|c|c|c|c|c|c|c|c|c|c|}
\hline Sample No. & $\begin{array}{l}{ }^{4} \mathrm{He} \\
\text { (ncc) }\end{array}$ & $\begin{array}{l}\text { Mass } \\
\text { (mg) }\end{array}$ & $\begin{array}{c}\mathrm{U} \\
(\mathrm{ppm})\end{array}$ & $\begin{array}{c}\text { Th } \\
\text { (ppm) }\end{array}$ & $\mathrm{Th} / \mathrm{U}$ & $\begin{array}{l}\mathrm{Rs}^{1} \\
(\mu \mathrm{m})\end{array}$ & $\mathrm{F}_{\mathrm{T}}{ }^{2}$ & $\begin{array}{l}\text { Corr. } \\
\text { Age } \\
\text { (Ma) }\end{array}$ & $\begin{array}{l}\text { Error } \\
( \pm 1 \sigma)\end{array}$ & $\begin{array}{l}\text { Weighted } \\
\text { Mean }^{3} \\
(\mathrm{Ma} \pm 1 \sigma)\end{array}$ & {$[\mathrm{eU}]^{4}$} \\
\hline BX321-3 & 0.124 & 0.0071 & 301.7 & 167.5 & 0.6 & 59.4 & 0.78 & 5.4 & 0.4 & & 341.1 \\
\hline BX321-4 & 0.122 & 0.0130 & 198.6 & 152.9 & 0.8 & 72.2 & 0.81 & 5.2 & 0.3 & & 234.5 \\
\hline \multicolumn{12}{|c|}{ Manianping transect } \\
\hline XLB16-21-1 & 0.390 & 0.0061 & 72.7 & 21.9 & 0.3 & 59.9 & 0.78 & 6.7 & 0.4 & $7.1 \pm 0.5$ & 77.9 \\
\hline XLB16-21-2 & 1.180 & 0.0126 & 94.4 & 51.7 & 0.5 & 78.6 & 0.83 & 7.2 & 0.4 & & 106.5 \\
\hline XLB16-21-3 & 0.592 & 0.0090 & 74.0 & 25.0 & 0.3 & 66.8 & 0.81 & 6.7 & 0.4 & & 79.8 \\
\hline XLB16-21-4 & 2.839 & 0.0154 & 156.6 & 62.8 & 0.4 & 73.7 & 0.83 & 8.8 & 0.5 & & 171.4 \\
\hline XLB16-21-5 & 0.692 & 0.0200 & 39.6 & 14.8 & 0.4 & 76.6 & 0.82 & 6.6 & 0.4 & & 43.1 \\
\hline XLB16-23-1 & 0.635 & 0.0154 & 48.2 & 19.1 & 0.4 & 85.2 & 0.84 & 6.4 & 0.4 & $7.2 \pm 0.7$ & 52.7 \\
\hline XLB16-23-2 & 1.621 & 0.0209 & 66.7 & 26.9 & 0.4 & 91.2 & 0.86 & 8.7 & 0.5 & & 73.0 \\
\hline XLB16-23-3 & 0.512 & 0.0078 & 69.0 & 23.5 & 0.3 & 63.0 & 0.80 & 7.2 & 0.4 & & 74.5 \\
\hline XLB16-23-4 & 0.511 & 0.0084 & 50.8 & 24.5 & 0.5 & 64.7 & 0.80 & 8.8 & 0.5 & & 56.6 \\
\hline XLB16-23-5 & 1.071 & 0.0108 & 121.8 & 32.1 & 0.3 & 72.8 & 0.83 & 6.3 & 0.4 & & 129.3 \\
\hline XLB16-25-1 & 0.367 & 0.0075 & 55.1 & 30.5 & 0.6 & 58.2 & 0.78 & 6.5 & 0.4 & $6.2 \pm 0.7$ & 62.2 \\
\hline XLB16-25-2 & 0.401 & 0.0076 & 54.3 & 21.5 & 0.4 & 57.7 & 0.78 & 7.4 & 0.5 & & 59.3 \\
\hline XLB16-25-3 & 0.458 & 0.0066 & 86.9 & 28.1 & 0.3 & 62.4 & 0.79 & 6.1 & 0.4 & & 93.5 \\
\hline XLB16-25-4 & 0.465 & 0.0099 & 65.8 & 27.3 & 0.4 & 67.1 & 0.81 & 5.4 & 0.3 & & 72.2 \\
\hline XLB16-3-1 & 3.555 & 0.0203 & 227.2 & 53.2 & 0.2 & 92.9 & 0.86 & 7.0 & 0.3 & $6.4 \pm 0.3$ & 239.7 \\
\hline XLB16-3-2 & 3.194 & 0.0154 & 324.6 & 98.2 & 0.3 & 72.1 & 0.83 & 5.9 & 0.3 & & 347.6 \\
\hline XLB16-3-3 & 3.046 & 0.0188 & 212.1 & 131.9 & 0.6 & 80.9 & 0.84 & 6.5 & 0.3 & & 243.1 \\
\hline XLB16-3-4 & 2.208 & 0.0138 & 229.2 & 85.7 & 0.4 & 79.0 & 0.84 & 6.3 & 0.3 & & 249.4 \\
\hline XLB16-5-1 & 0.788 & 0.0064 & 192.0 & 158.0 & 0.8 & 53.3 & 0.76 & 5.8 & 0.3 & $6.0 \pm 0.3$ & 229.2 \\
\hline XLB16-5-2 & 0.410 & 0.0050 & 137.2 & 95.0 & 0.7 & 49.8 & 0.75 & 5.7 & 0.3 & & 159.5 \\
\hline XLB16-5-3 & 1.898 & 0.0077 & 393.1 & 205.8 & 0.5 & 57.0 & 0.78 & 5.9 & 0.3 & & 441.5 \\
\hline XLB16-5-4 & 3.652 & 0.0056 & 981.2 & 282.2 & 0.3 & 52.0 & 0.76 & 6.7 & 0.3 & & 1047.5 \\
\hline XLB16-7-1 & 1.141 & 0.0055 & 351.2 & 132.1 & 0.4 & 50.1 & 0.75 & 6.0 & 0.3 & $5.4 \pm 0.6$ & 382.3 \\
\hline XLB16-7-2 & 2.524 & 0.0051 & 742.0 & 363.3 & 0.5 & 51.8 & 0.76 & 6.5 & 0.3 & & 827.4 \\
\hline XLB16-7-3 & 0.223 & 0.0073 & 56.3 & 44.8 & 0.8 & 58.4 & 0.78 & 4.8 & 0.2 & & 66.9 \\
\hline XLB16-7-4 & 0.368 & 0.0067 & 101.7 & 47.7 & 0.5 & 56.3 & 0.78 & 5.1 & 0.3 & & 112.9 \\
\hline
\end{tabular}

${ }^{1}$ Radius of a sphere with the equivalent surface area-to-volume ratio as cylindrical crystals (Meesters \& Dunai, 2002).

${ }^{2}$ FT is the a-ejection correction after Farley et al. [1996].

${ }^{3}$ Weighted means at 95\% confidence level calculated using Isoplot V3.59 [Ludwig, 1991].

${ }^{4}$ Effective Uranium content, [eU] =U+ 0.235Th ppm [Flowers et al., 2007]. 
Table 4. Single-grain apatite (U-Th)/He results from Caopo transect of Xuelongbao massif, central Longmen Shan

\begin{tabular}{|c|c|c|c|c|c|c|c|c|c|c|c|c|}
\hline Sample No. & $\begin{array}{l}{ }^{4} \mathrm{He} \\
\text { (ncc) }\end{array}$ & $\begin{array}{l}\text { Mass } \\
\text { (mg) }\end{array}$ & $\begin{array}{c}\mathrm{U} \\
\text { (ppm) }\end{array}$ & $\begin{array}{c}\text { Th } \\
\text { (ppm) }\end{array}$ & $\begin{array}{c}\mathrm{Sm} \\
(\mathrm{ppm})\end{array}$ & $\mathrm{Th} / \mathrm{U}$ & $\begin{array}{l}\mathrm{Rs}^{1} \\
(\mu \mathrm{m})\end{array}$ & $\mathrm{F}_{\mathrm{T}}{ }^{2}$ & $\begin{array}{l}\text { Corr. } \\
\text { Age } \\
\text { (Ma) }\end{array}$ & $\begin{array}{l}\text { Error } \\
( \pm 1 \sigma)\end{array}$ & $\begin{array}{c}\text { Weighted } \\
\text { Mean }^{3} \\
(\mathrm{Ma} \pm 1 \sigma)\end{array}$ & {$[\mathrm{eU}]^{4}$} \\
\hline XLB16-11-1 & 0.117 & 0.0300 & 8.7 & 7.4 & 94.5 & 0.8 & 70.7 & 0.81 & 3.5 & 0.2 & $4.1 \pm 0.2$ & 10.4 \\
\hline XLB16-11-2 & 0.105 & 0.0145 & 14.7 & 9.4 & 30.4 & 0.6 & 71.8 & 0.82 & 4.3 & 0.3 & & 16.9 \\
\hline XLB16-11-3 & 0.331 & 0.0346 & 17.3 & 14.1 & 9.4 & 0.8 & 70.4 & 0.81 & 4.4 & 0.3 & & 20.6 \\
\hline XLB16-11-4 & 0.105 & 0.0202 & 9.7 & 11.0 & 40.6 & 1.1 & 65.9 & 0.80 & 4.1 & 0.2 & & 12.2 \\
\hline XLB16-11-5 & 0.103 & 0.0270 & 7.9 & 5.3 & 30.6 & 0.7 & 77.6 & 0.83 & 4.0 & 0.2 & & 9.2 \\
\hline XLB16-11-6 & 0.072 & 0.0133 & 10.5 & 7.4 & 30.6 & 0.7 & 68.8 & 0.81 & 4.4 & 0.3 & & 12.3 \\
\hline XLB16-13-1 & 0.019 & 0.0074 & 6.5 & 4.1 & 39.0 & 0.6 & 63.9 & 0.80 & 3.6 & 0.2 & $3.0 \pm 0.4$ & 7.4 \\
\hline XLB16-13-2 & 0.003 & 0.0070 & 2.3 & 3.8 & 9.1 & 1.7 & 63.0 & 0.80 & 1.4 & 0.1 & & 3.2 \\
\hline XLB16-13-3 & 0.008 & 0.0074 & 3.8 & 2.4 & 26.8 & 0.6 & 54.5 & 0.77 & 2.5 & 0.1 & & 4.3 \\
\hline XLB16-13-4 & 0.011 & 0.0091 & 3.1 & 1.7 & 20.4 & 0.6 & 59.8 & 0.79 & 3.5 & 0.2 & & 3.5 \\
\hline XLB16-13-5 & 0.016 & 0.0068 & 5.6 & 3.5 & 9.0 & 0.6 & 55.3 & 0.77 & 3.9 & 0.2 & & 6.5 \\
\hline XLB16-13-6 & 0.020 & 0.0065 & 6.8 & 6.9 & 15.7 & 1.0 & 55.2 & 0.77 & 3.9 & 0.2 & & 8.5 \\
\hline XLB16-16-1 & 0.059 & 0.0069 & 20.3 & 14.8 & 37.7 & 0.7 & 62.0 & 0.79 & 3.8 & 0.2 & $3.9 \pm 0.1$ & 23.8 \\
\hline XLB16-16-2 & 0.030 & 0.0063 & 11.2 & 10.1 & 12.5 & 0.9 & 72.6 & 0.82 & 3.8 & 0.2 & & 13.6 \\
\hline XLB16-16-3 & 0.023 & 0.0043 & 12.9 & 6.4 & 40.5 & 0.5 & 61.0 & 0.79 & 4.1 & 0.2 & & 14.5 \\
\hline XLB16-16-4 & 0.017 & 0.0076 & 5.5 & 4.4 & 41.0 & 0.8 & 58.1 & 0.78 & 3.6 & 0.2 & & 6.5 \\
\hline XLB16-16-5 & 0.074 & 0.0044 & 35.7 & 39.9 & 9.5 & 1.1 & 69.0 & 0.81 & 4.1 & 0.2 & & 45.1 \\
\hline XLB16-16-6 & 0.024 & 0.0055 & 10.2 & 8.5 & 120.5 & 0.8 & 109.3 & 0.86 & 3.9 & 0.2 & & 12.2 \\
\hline XLB16-18-1 & 0.042 & 0.0248 & 6.2 & 2.7 & 7.9 & 0.4 & 82.3 & 0.82 & 2.4 & 0.1 & $3.0 \pm 0.2$ & 6.8 \\
\hline XLB16-18-2 & 0.101 & 0.0285 & 8.8 & 6.4 & 45.5 & 0.7 & 111.2 & 0.86 & 3.3 & 0.2 & & 10.3 \\
\hline XLB16-18-3 & 0.055 & 0.0194 & 7.1 & 7.3 & 41.0 & 1.0 & 95.7 & 0.84 & 3.2 & 0.2 & & 8.8 \\
\hline XLB16-18-4 & 0.089 & 0.0201 & 10.1 & 6.8 & 50.6 & 0.7 & 107.1 & 0.86 & 3.7 & 0.2 & & 11.7 \\
\hline XLB16-18-5 & 0.030 & 0.0213 & 5.0 & 1.1 & 19.4 & 0.2 & 83.9 & 0.82 & 2.6 & 0.1 & & 5.2 \\
\hline XLB16-18-6 & 0.065 & 0.0195 & 9.8 & 3.8 & 29.1 & 0.4 & 67.9 & 0.78 & 3.1 & 0.2 & & 10.7 \\
\hline XLB16-18-7 & 0.116 & 0.0249 & 10.6 & 9.2 & 37.8 & 0.9 & 67.6 & 0.77 & 3.5 & 0.2 & & 12.8 \\
\hline BX318-1 & 0.072 & 0.0185 & 9.7 & 5.8 & 30.0 & 0.6 & 97.4 & 0.85 & 3.4 & 0.2 & $3.6 \pm 0.3$ & 11.1 \\
\hline BX318-2 & 0.080 & 0.0179 & 8.3 & 5.3 & 28.7 & 0.6 & 99.4 & 0.85 & 4.7 & 0.2 & & 9.6 \\
\hline BX318-3 & 0.068 & 0.0110 & 12.5 & 7.5 & 35.4 & 0.6 & 94.7 & 0.84 & 4.4 & 0.2 & & 14.3 \\
\hline BX318-4 & 0.036 & 0.0078 & 11.6 & 8.6 & 25.3 & 0.7 & 101.8 & 0.86 & 3.5 & 0.2 & & 13.7 \\
\hline BX318-5 & 0.048 & 0.0152 & 9.1 & 6.2 & 21.9 & 0.7 & 71.0 & 0.79 & 2.9 & 0.1 & & 10.5 \\
\hline BX318-6 & 0.079 & 0.0157 & 9.7 & 8.6 & 45.1 & 0.9 & 81.7 & 0.82 & 4.3 & 0.2 & & 11.7 \\
\hline BХ318-7 & 0.044 & 0.0072 & 16.9 & 11.8 & 50.4 & 0.7 & 91.7 & 0.84 & 3.3 & 0.2 & & 19.6 \\
\hline
\end{tabular}




\begin{tabular}{|c|c|c|c|c|c|c|c|c|c|c|c|c|}
\hline Sample No. & $\begin{array}{l}{ }^{4} \mathrm{He} \\
\text { (ncc) }\end{array}$ & $\begin{array}{l}\text { Mass } \\
(\mathrm{mg})\end{array}$ & $\begin{array}{c}\mathrm{U} \\
\text { (ppm) }\end{array}$ & $\begin{array}{c}\text { Th } \\
\text { (ppm) }\end{array}$ & $\begin{array}{c}\mathrm{Sm} \\
(\mathrm{ppm})\end{array}$ & $\mathrm{Th} / \mathrm{U}$ & $\begin{array}{l}\mathrm{Rs}^{1} \\
(\mu \mathrm{m})\end{array}$ & $\mathrm{F}_{\mathrm{T}}^{2}$ & $\begin{array}{l}\text { Corr. } \\
\text { Age } \\
\text { (Ma) }\end{array}$ & $\begin{array}{l}\text { Error } \\
( \pm 1 \sigma)\end{array}$ & $\begin{array}{c}\text { Weighted } \\
\text { Mean }^{3} \\
(\mathrm{Ma} \pm 1 \sigma)\end{array}$ & {$[\mathrm{eU}]^{4}$} \\
\hline ВХ317-1 & 0.012 & 0.0088 & 4.0 & 3.7 & 9.7 & 0.9 & 70.1 & 0.78 & 2.9 & 0.1 & $2.8 \pm 0.3$ & 4.8 \\
\hline ВХ317-2 & 0.016 & 0.0057 & 9.3 & 9.1 & 11.4 & 1.0 & 58.0 & 0.74 & 2.7 & 0.1 & & 11.4 \\
\hline ВX317-3 & 0.014 & 0.0103 & 4.8 & 5.8 & 9.6 & 1.2 & 58.3 & 0.74 & 2.3 & 0.1 & & 6.1 \\
\hline ВХ317-4 & 0.063 & 0.0157 & 6.9 & 6.1 & 15.9 & 0.9 & 104.6 & 0.86 & 4.8 & 0.2 & & 8.3 \\
\hline ВХ317-5 & 0.026 & 0.0087 & 7.7 & 7.4 & 19.9 & 1.0 & 107.4 & 0.86 & 3.3 & 0.2 & & 9.4 \\
\hline ВХ317-6 & 0.024 & 0.0079 & 7.3 & 7.3 & 17.3 & 1.0 & 92.7 & 0.84 & 3.6 & 0.2 & & 9.0 \\
\hline ВX316-1 & 0.024 & 0.0078 & 11.0 & 8.5 & 24.8 & 0.8 & 67.9 & 0.78 & 2.4 & 0.1 & $2.5 \pm 0.1$ & 13.0 \\
\hline ВX316-2 & 0.060 & 0.0134 & 16.0 & 8.3 & 45.1 & 0.5 & 75.2 & 0.80 & 2.5 & 0.1 & & 18.0 \\
\hline ВХ316-3 & 0.071 & 0.0193 & 11.0 & 7.5 & 44.8 & 0.7 & 66.6 & 0.77 & 2.8 & 0.1 & & 12.8 \\
\hline ВХ316-4 & 0.024 & 0.0126 & 5.2 & 6.3 & 3.2 & 1.2 & 66.5 & 0.77 & 2.9 & 0.1 & & 6.7 \\
\hline ВX316-5 & 0.041 & 0.0246 & 5.0 & 4.6 & 6.8 & 0.9 & 67.1 & 0.77 & 2.6 & 0.1 & & 6.0 \\
\hline ВХ316-6 & 0.033 & 0.0135 & 9.0 & 8.6 & 20.9 & 1.0 & 62.8 & 0.76 & 2.2 & 0.1 & & 11.0 \\
\hline ВX316-7 & 0.109 & 0.0199 & 20.8 & 10.4 & 32.5 & 0.5 & 57.4 & 0.74 & 2.3 & 0.1 & & 23.3 \\
\hline BX221-1 & 0.014 & 0.0073 & 8.0 & 6.8 & 14.0 & 0.8 & 82.0 & 0.82 & 2.1 & 0.1 & $2.4 \pm 0.1$ & 9.6 \\
\hline BX221-2 & 0.025 & 0.0071 & 12.1 & 9.9 & 18.7 & 0.8 & 105.3 & 0.86 & 2.6 & 0.1 & & 14.5 \\
\hline BX221-3 & 0.036 & 0.0100 & 12.1 & 11.8 & 21.8 & 1.0 & 84.8 & 0.83 & 2.5 & 0.1 & & 14.9 \\
\hline BX221-4 & 0.020 & 0.0054 & 12.5 & 11.3 & 22.1 & 0.9 & 95.2 & 0.85 & 2.6 & 0.1 & & 15.1 \\
\hline BX221-6 & 0.024 & 0.0072 & 12.7 & 10.4 & 21.4 & 0.8 & 72.9 & 0.77 & 2.3 & 0.1 & & 15.1 \\
\hline BX221-7 & 0.028 & 0.0083 & 13.9 & 8.7 & 9.4 & 0.6 & 61.6 & 0.73 & 2.2 & 0.1 & & 15.9 \\
\hline
\end{tabular}

${ }^{1}$ Radius of a sphere with the equivalent surface area-to-volume ratio as cylindrical crystals (Meesters \& Dunai, 2002).

${ }^{2}$ FT is the a-ejection correction after Farley et al. [1996].

${ }^{3}$ Weighted means at 95\% confidence level calculated using Isoplot V3.59 [Ludwig, 1991]. Evidently younger or older age outliers are highlighted in grey shading and are excluded from calculation of the weighted mean age.

${ }^{4}$ Effective Uranium content, [eU] =U+ 0.235Th ppm [Flowers et al., 2007].

Table 5. Parameters used in Pecube modeling

\begin{tabular}{lccc}
\hline Parameter Name & Parameter Range & Units & Reference \\
\hline Thermal conductivity & 2.5 & $\mathrm{~W} / \mathrm{m} / \mathrm{K}$ & Whipp et al. [2007] \\
Crustal density & 2700 & $\mathrm{~kg} / \mathrm{m}^{3}$ & \\
Thermal diffusivity & 25 & $\mathrm{~km} / \mathrm{My}$ & \\
Mean annual surface temperature & 25 & ${ }^{\circ} \mathrm{C}$ &
\end{tabular}


Atmospheric lapse rate

Model time step

Horizontal node spacing

Vertical node spacing

Model starting time

Transitional time

Relief factor at the transitional time

Basal temperature (model shown in figure 6)

Basal temperature (model shown in figure S3)

Exhumation rate before and after the transitional time

$\begin{array}{ccc}6 & { }^{\circ} \mathrm{C} / \mathrm{km} & \text { Naito et al. [2006] } \\ \text { Optimal } & \text { years } \\ 0.9 & \mathrm{~km} \\ 0.9 & \mathrm{~km} \\ 20 & \mathrm{Ma} \\ 1-18 & \mathrm{Ma} \\ 0.5-1.5 & - \\ 00-700 & { }^{\circ} \mathrm{C} \\ 00-900 & { }^{\circ} \mathrm{C} \\ 0-3 & \mathrm{~km} / \mathrm{m} . \mathrm{y} .\end{array}$




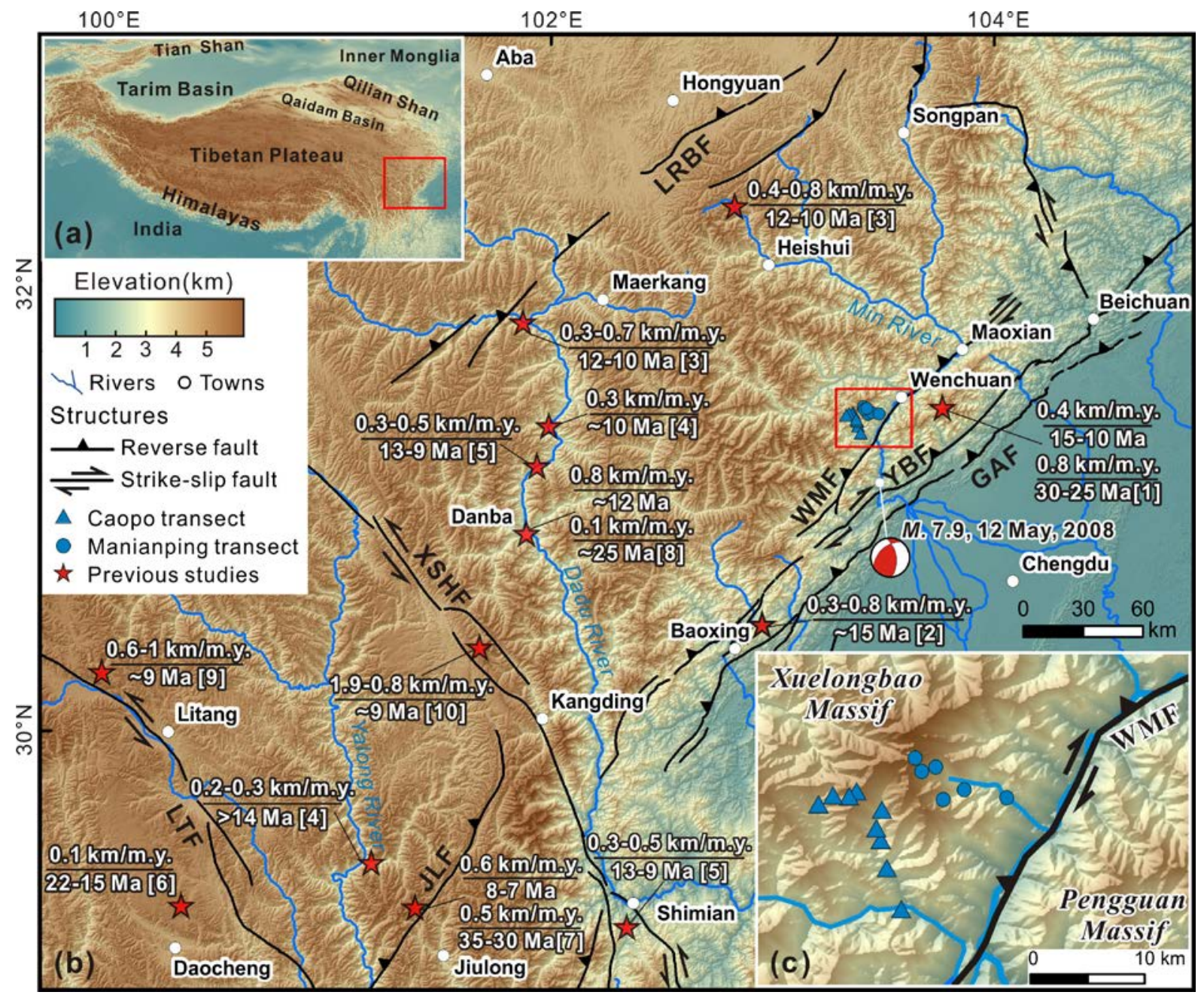

Figure 1. Tectonics and regional topography of the eastern Tibetan Plateau. (a) Digital elevation model of the topography of the Tibetan Plateau, showing the location of the study area (red rectangle). (b) Digital elevation model of the topography and active faults in and around the study area. Previous determinations for the exhumation rate and the age of the onset of rapid exhumation at sites marked by red stars are also shown. Faults are simplified from the work of Xu et al. [1992], Burchfiel et al. [1995], Chen et al. [1995], Densmore et al. [2007], Xue et al. [2017] and Yan et al. [2018]. Abbreviations: WMF = Wenchuan-Maoxian fault; YBF = Yingxiu-Beichuan fault; GAF = Guanxian-Anxian fault; LRBF = Longriba fault; LTF $=$ Litang fault; JLF = Jiulong fault; XSHF = Xianshuihe fault. Reference codes are: $1=$ Wang et al. [2012]; 2 = Tian et al. [2013] and Cook et al. [2013]; 3 = Tian et al. [2015] and Ansberque et al. [2018]; 4 = Ouimet et al. [2010]; 5 = Clark et al. [2005]; $6=$ Tian et al. [2014]; 7 = Zhang et al. [2016]; 8 = Tan et al. [2017b]; 9 = Zhang et al. [2015]; $10=$ Zhang et al. [2017]. The red rectangle shows the locality of this study. (c) Topographic map (SRTM) of the study area, showing sample locations, river network and Wenchuan-Maoxian fault. 
Samples from the Caopo and Manianping transects are shown by blue triangles and circles, respectively.

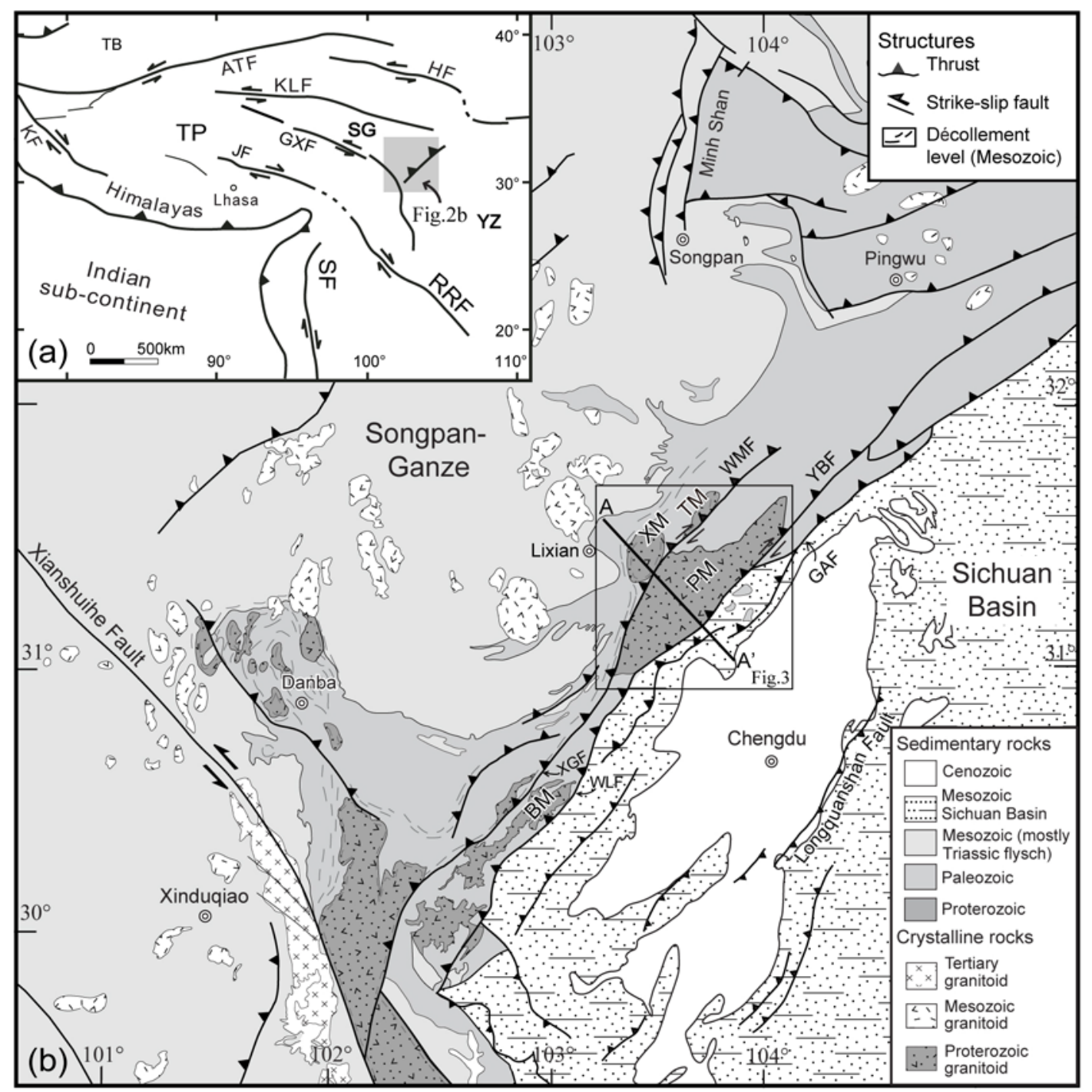

(c)

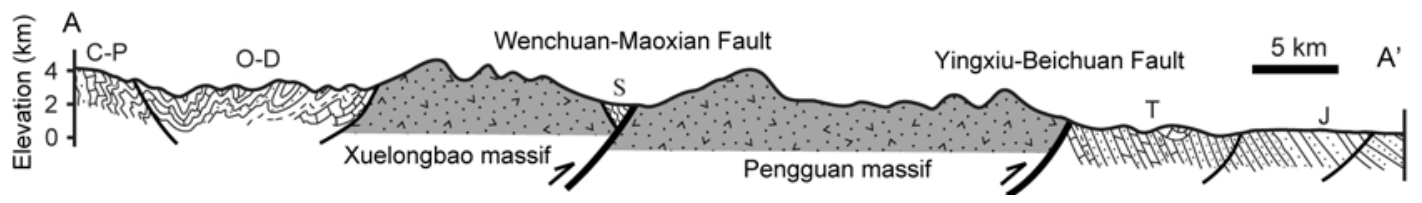

Figure 2. (a) Tectonic map showing main structures of the Tibetan Plateau and location of the Longmen Shan. Abbreviations: ATF = Altyn Tagh Fault; GXF = Ganzi-Xianshuihe 
Fault; HF = Haiyuan Fault; JF = Jiali Fault; KLF = Kunlun Fault; KF = Karakorum Fault; RRF = Red River Fault; SF = Sagaing fault, SG = Songpan-Ganze terrane, YZ = Yangtze terrane, $\mathrm{TB}=$ Tarim Basin, $\mathrm{TP}=$ Tibetan Plateau. Cross section A-A' are shown below. (b) Generalized geology map of the Longmen Shan and its vicinity, modified after SBGMR [1991], Burchfiel et al. [1995], Roger et al. [2004], Xu et al. [2008] and Tian et al. [2013]. Indexes for fault zones: $\mathrm{WMF}=$ Wenchuan-Maoxian Fault, $\mathrm{YBF}=$ Yingxiu-Beichuan Fault, GAF $=$ Guanxian-Anxian Fault, XGF $=$ Xiaoguanzi Fault, WLF $=$ Wulong Fault. Abbreviations: $\mathrm{XM}=$ Xuelongbao massif; $\mathrm{PM}=$ Pengguan massif; $\mathrm{TM}$ = Tonghua massif; $\mathrm{BM}=$ Baoxing massif. (c) A geological cross-section across the Xuelongbao and Pengguan massifs based on field structural analysis and seismic profile [for locations see panel b], after Worley and Wilson [1996], Jin et al. [2010], Airaghi et al. [2017], Xue et al. [2017] and Yan et al. [2018]. 


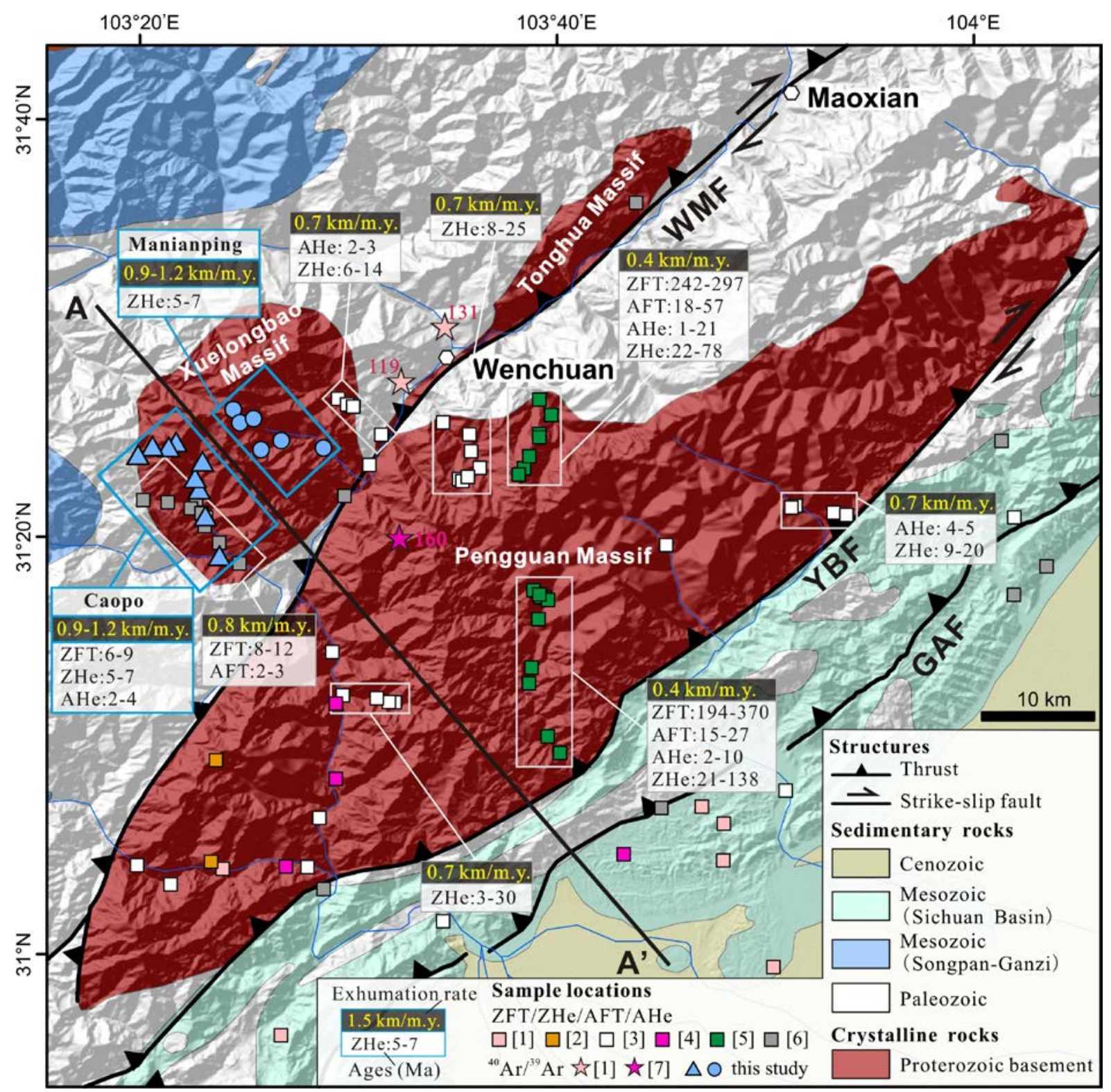

Figure 3. Simplified geological map of the central Longmen Shan. Locations of samples collected for this study are shown along two elevation transects (blue triangles and circles for Caopo transect and Manianping transect, respectively) in the Xuelongbao massif, a crystalline massif in the hanging wall of the Wenchuan-Maoxian Fault. Data from previous studies are available in the Supplementary Information. Reference codes are: $1=$ Arne et al. [1997]; 2 = Kirby et al. [2002]; 3 = Godard et al. [2009]; 4 = Wilson and Fowler [2011]; 5 = Wang et al. [2012]; $6=$ Tan et al. [2017a]; $7=$ Yan et al. [2008]. Abbreviations: WMF = 
Wenchuan-Maoxian Fault, YBF = Yingxiu-Beichuan Fault, GAF = Guanxian-Anxian Fault.

This article is protected by copyright. All rights reserved. 

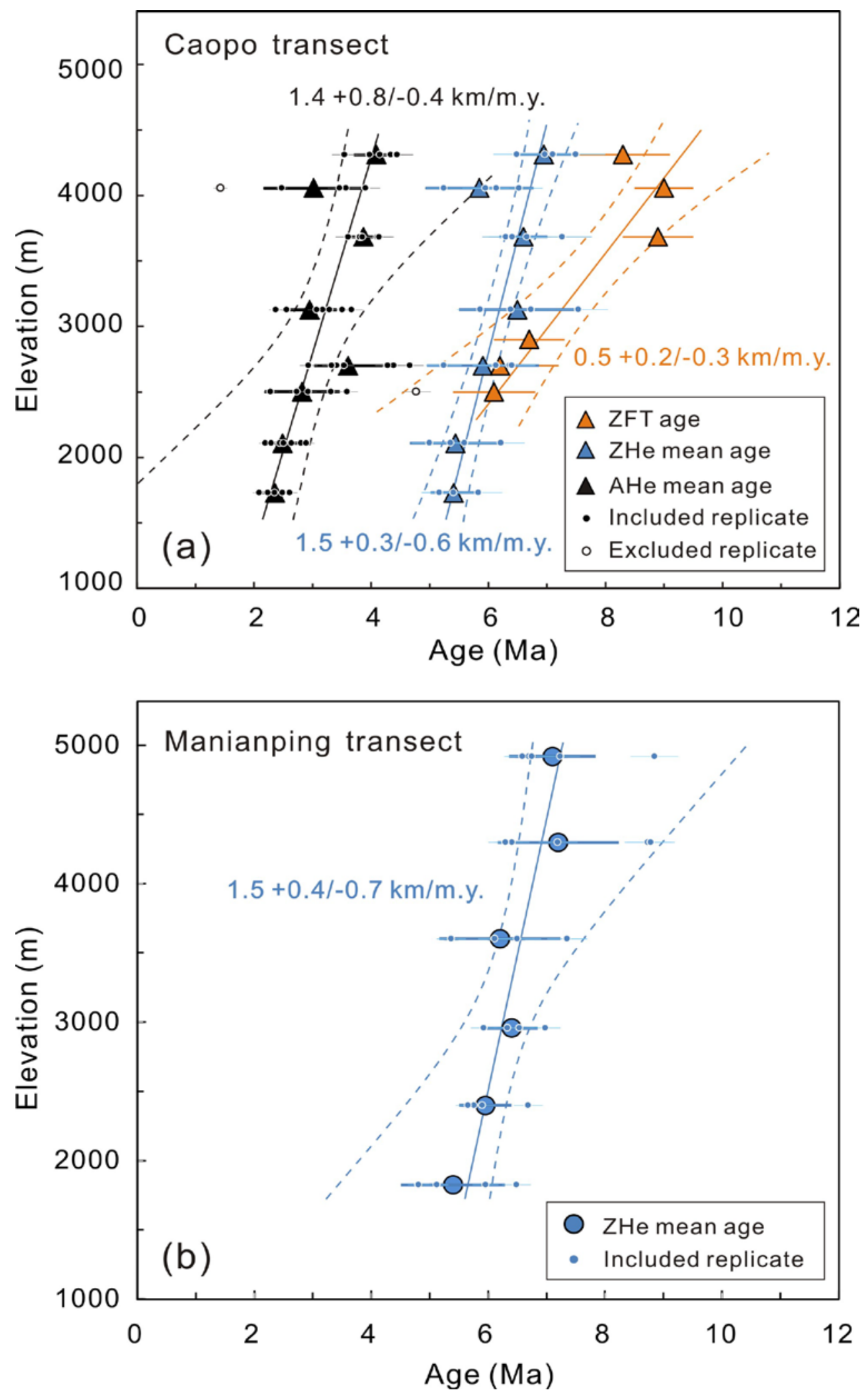

This article is protected by copyright. All rights reserved. 
Figure 4. Age-elevation transects for thermochronologic data showing (a) ZFT ages, ZHe ages and AHe ages for the Caopo transect and (b) ZHe ages for the Manianping transect. The straight lines are least squares regressions assuming a single exhumation event with 95\% confidence interval. Filled symbols denote grain replicates included in the mean age determination. Open symbols are grain ages excluded. Solid and dashed lines denote best-fits and $\pm 1 \sigma$ variations of robust linear regression of the age-elevation correlations. 


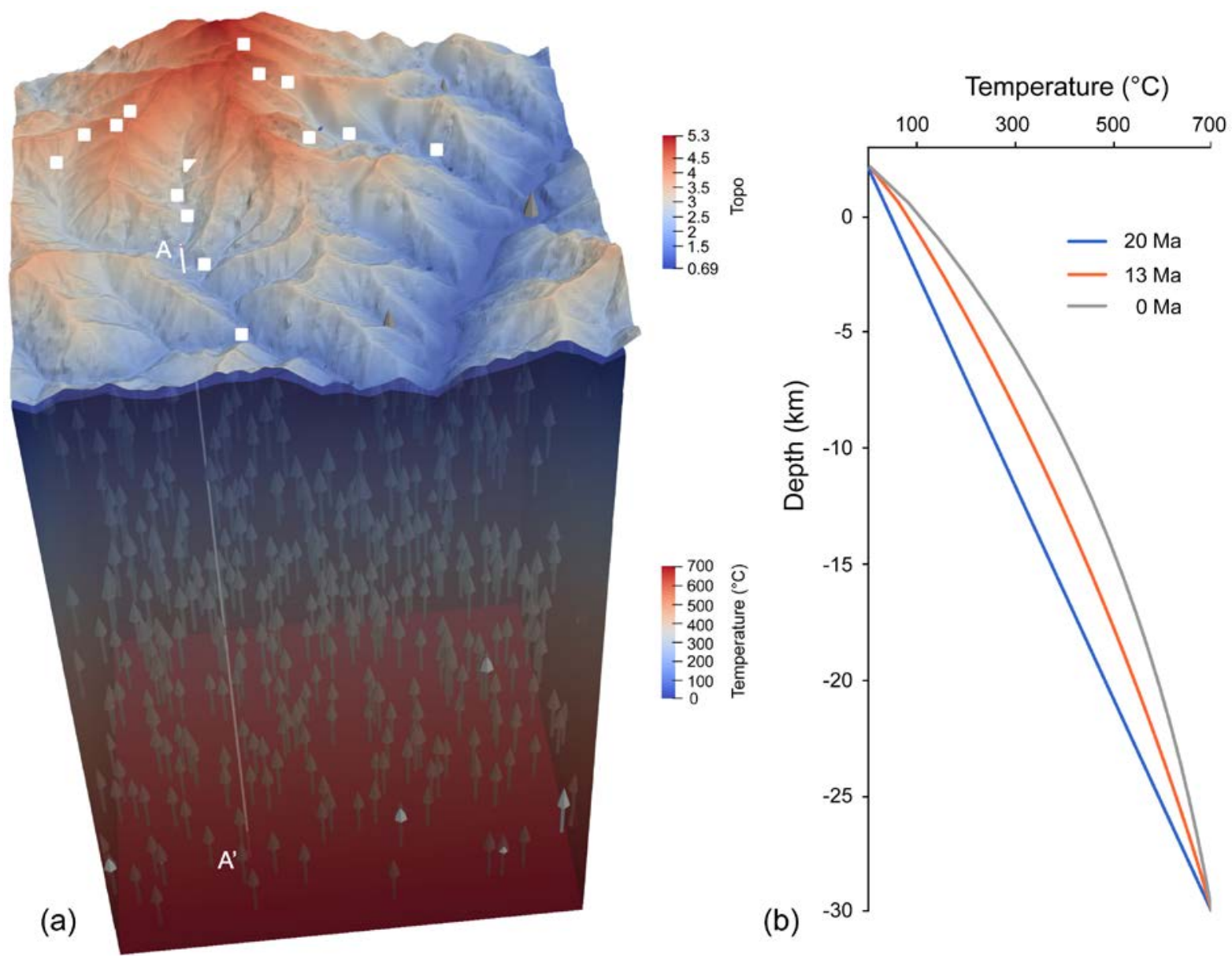

Figure 5. (a) Model setup for the 3D thermo-kinematic modeling of this work (parameters are given in Table 5). The model calculates evolving thermal field of a 30-km-thick crustal block using a combination of geothermal, rock exhumation (grey arrows), landscape evolution parameters. The topography is scaled from SRTM digital elevation model by a relief factor (R). Samples from which thermochronological ages have been determined and used as model inputs are marked as white squares on top of the topography. (b) Temperature - depth plots at the starting time (20 Ma), the best-fit transitional time ( 13 Ma, see figure 6 ) and the present-day (0 Ma) along the synthetic borehole A-A'. The predicted temperature profile yields a current geothermal gradient of $30-35{ }^{\circ} \mathrm{C} / \mathrm{km}$. 

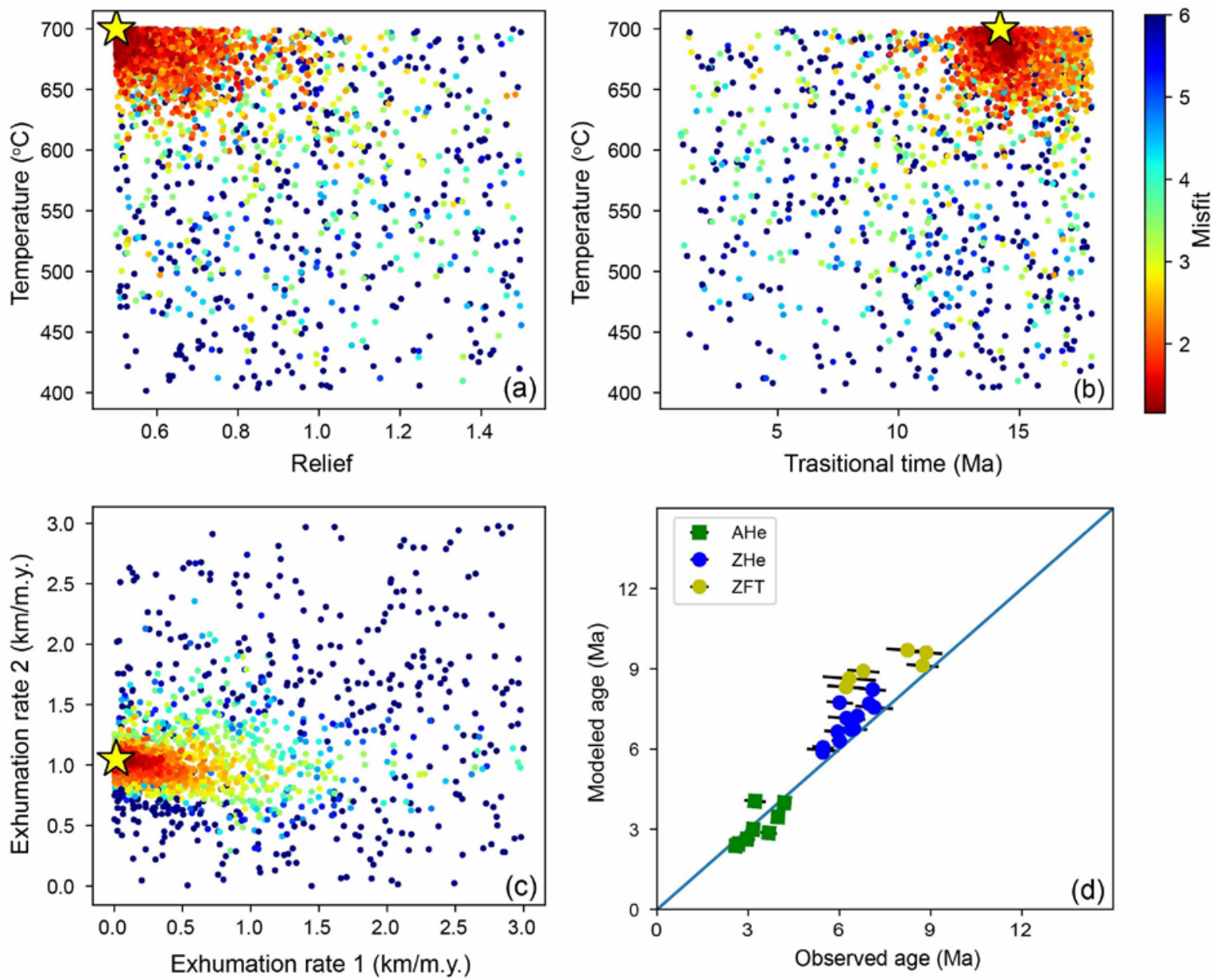

Figure 6. 2D scatter diagrams showing (a-c) results of the NA inversion and (d) comparison between observations and predictions by the best-fit model. Panels a-c are the projection of the full parameter space onto a plane defined by two of the five parameters: (a) relief ratio versus transitional time, (b) exhumation rates before (E1) and after (E2) the transitional time, (c) relief ratio versus basal temperature. In each of these three panels, each dot corresponds to a forward model, which is color-coded by the value of misfit between predictions and input observations. The best-fit model with minimum misfit is marked by yellow star in each plot. Panel (d) compares the observations and modeled predictions by the best-fit model. 


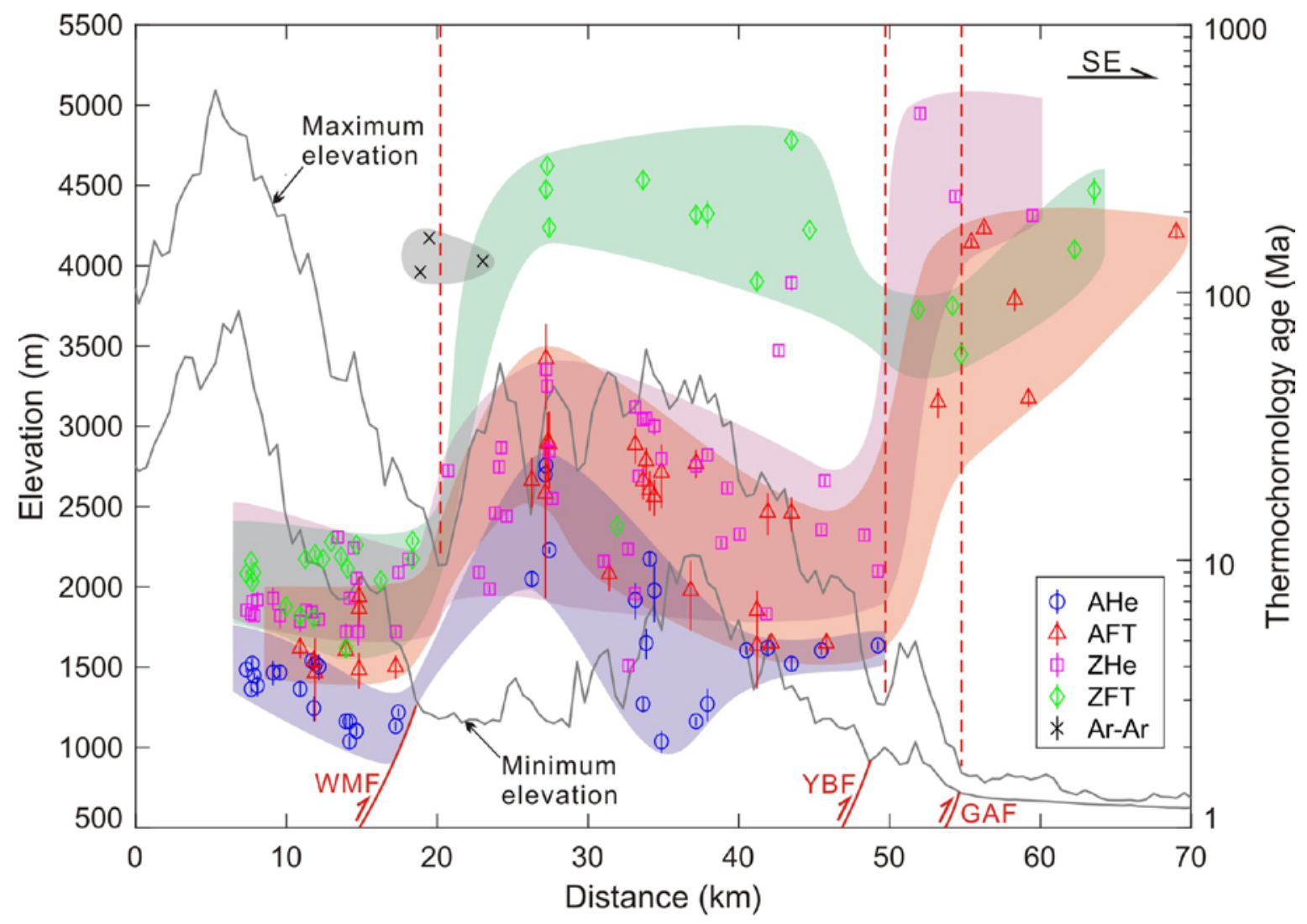

Figure 7. Projection of low-temperature thermochronology data compiled in Figure 3, along the central Longmen Shan swath (A-A'). For location of the swath, see Figure 3. Topographic features were calculated using a $10 \mathrm{~km}$ circle window. Vertical dashed lines show the surface locations of the fault zones. The panel shows apparent lateral differences in thermochronological ages across the Wenchuan-Maoxian and Yingxiu-Beichuan faults. Details of data plotted are compiled in Tables S5. Fault notation as for Fig. 1b. 


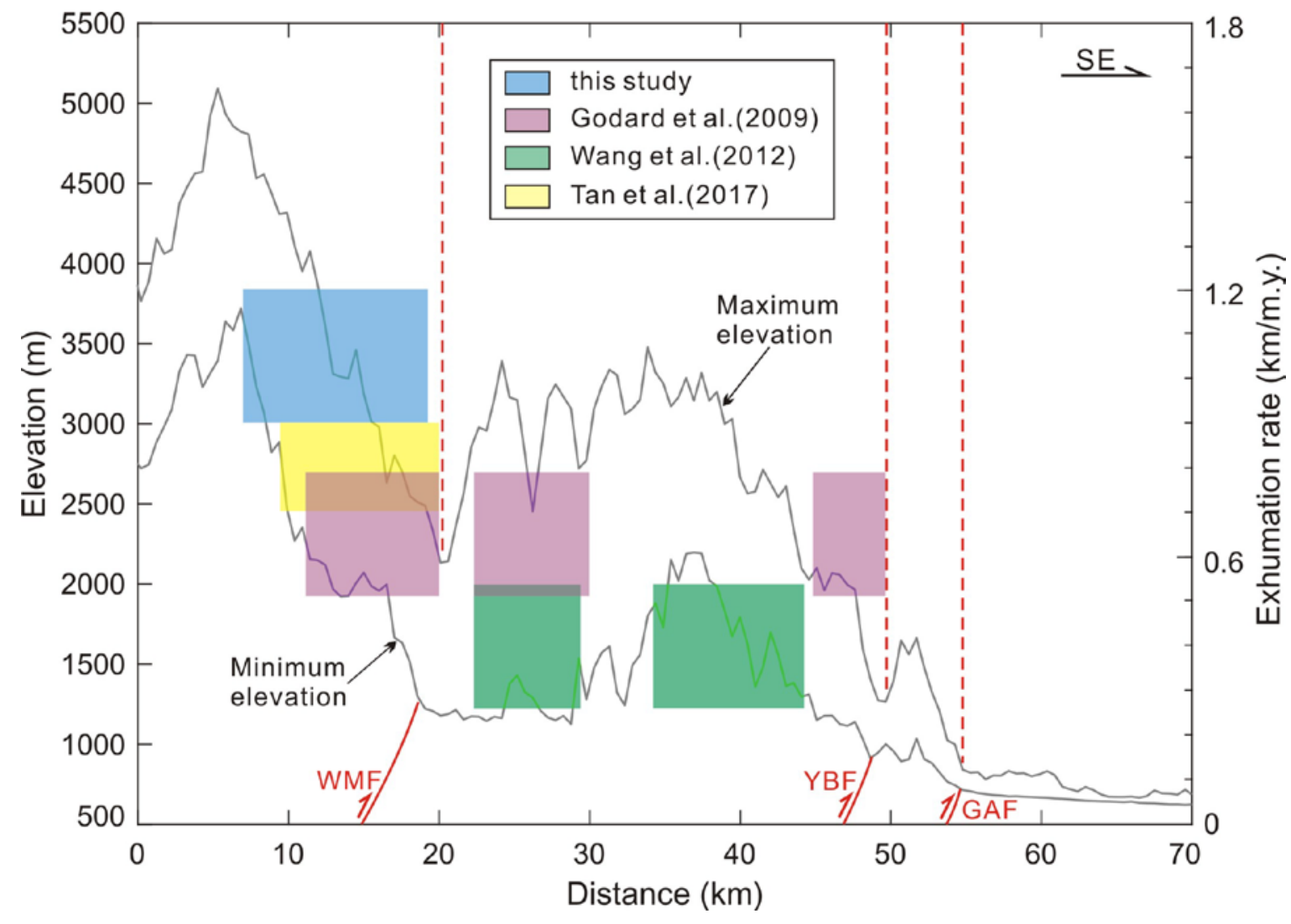

Figure 8. Projection of exhumation rates from data in vertical profiles in the Xuelongbao and Pengguan massifs (compiled in Figure 3) along the central Longmen Shan swath (A-A'). Data highlight the clear difference in exhumation rate across the Wenchuan-Maoxian fault. See Figure 3 for location of swath. Fault notation as for Fig. $1 \mathrm{~b}$. 


\section{University Library}

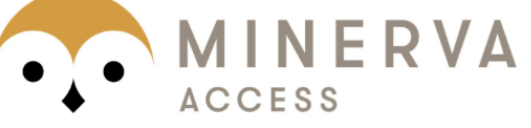

A gateway to Melbourne's research publications

Minerva Access is the Institutional Repository of The University of Melbourne

Author/s:

Shen, X;Tian, Y;Zhang, G;Zhang, S;Carter, A;Kohn, B;Vermeesch, P;Liu, R;Li, W

Title:

Late Miocene Hinterland Crustal Shortening in the Longmen Shan Thrust Belt, the Eastern Margin of the Tibetan Plateau

Date:

2019-11-13

Citation:

Shen, X., Tian, Y., Zhang, G., Zhang, S., Carter, A., Kohn, B., Vermeesch, P., Liu, R. \& Li, W. (2019). Late Miocene Hinterland Crustal Shortening in the Longmen Shan Thrust Belt, the Eastern Margin of the Tibetan Plateau. JOURNAL OF GEOPHYSICAL RESEARCH-SOLID EARTH, 124 (11), pp.11972-11991. https://doi.org/10.1029/2019JB018358.

Persistent Link:

http://hdl.handle.net/11343/286614 